\title{
Paleoseismic record obtained by coring a sag-pond along the North Anatolian Fault (Turkey)
}

\author{
Aurelia Hubert-Ferrari ${ }^{1, \star}$, Ulas Avsar ${ }^{2}$, Meriam El Ouahabi ${ }^{1}$, Gilles Lepoint ${ }^{1}$, \\ Philippe Martinez ${ }^{3}$, Nathalie Fagel ${ }^{1}$ \\ ${ }^{1}$ University of Liege, Unit of Physical and Quaternary Geography, Liège, Belgium \\ ${ }^{2}$ Ghent University, Renard Centre of Marine Geology, Department of Geology and Soil Science, Ghent, Belgium \\ ${ }^{3}$ UMR 5805 EPOC - OASU, Université Bordeaux 1, Talence, Bordeaux, France
}

\author{
Article history \\ Received October 31, 2011; accepted July 7, 2012. \\ Subject classification: \\ Earthquake geology and paleoseismology, Tectonics, Seismites, Sedimentary cores, North Anatolian Fault.
}

\begin{abstract}
Shallow lakes along minor structural bends or discontinuities of strikeslip faults are not usually paleoseismological target sites. In the present study, we show that a 2-m-deep, 700-m-long lake that is cross-cut by the North Anatolian Fault contains a reliable paleoseimological record that can be obtained through coring. The North Anatolian Fault is a major strike-slip fault in Turkey, and it last ruptured across the Aşağitepecik Lake in 1939, with a slip of about $6 \mathrm{~m}$. Seismic lines still show remains of the fault rupture in the form of minor scarps across the lake. Collected short cores show a set of sedimentary sequences. Each sequence is composed of similar organic-rich sedimentary units. The lower unit is dark and fibrous, and is similar to the present sedimentation at the top of the core. The upper unit is disturbed and has anomalous organic matter content, grain size and mineralogy. It is interpreted as an earthquake-induced sedimentary event. The 2.5-m-long AT2007LG core comprises four sequences, and four sedimentary events. Radiogenic ${ }^{210} \mathrm{~Pb}$ and ${ }^{137} \mathrm{Cs}$ data obtained previously imply that the shallowest event 1 was triggered by the $1939 M=7.9$ Erzincan earthquake. Radiocarbon dating and correlation to a reference varved record suggest that events 2 and 4 were initiated by the 1668 and 1254 historical earthquakes. Event 3 does not correspond to a large historical earthquake on the North Anatolian Fault.
\end{abstract}

\section{Introduction}

Constraining the rupture history of a given strike-slip fault can be challenging. There is the need for a site where continuous and slow trapping of sediments occurs. These key sites are thus often located along structural discontinuities, like pull-apart basins and releasing bends present at different scales along strike-slip faults. These sedimentary traps have been exploited to retrieve continuous paleoseismological records along different strike-slip fault systems throughout the world [Klinger et al. 2003, Weldon et al. 2004, Liu et al. 2007, Kozac1 et al. 2011]. Some of these tectonic depressions can be underwater, thus forming lakes, ponds or wet- lands, and it is not possible to expose their sedimentary record in classical paleoseismological trenches [McCalpin 2009]. However, a paleoseismic record can still be obtained by coring, as in the present study.

Sedimentary cores have been used to retrieve long records of paleoearthquakes in different environments: suburban areas [e.g., Leon et al. 2009], lakes [e.g., Schnellmann et al. 2002, Becker et al. 2005, Bertrand et al. 2007, Carrillo et al. 2008, Beck 2009], lagoons [Bertrand et al. 2011], small oceanic basins [e.g., Gorsline et al. 2000] and oceans [Nakajima and Kanai 2000, Goldfinger et al. 2003, Goldfinger et al. 2006, Beck et al. 2007, Goldfinger et al. 2007]. The earthquake history is inferred using indirect sedimentological imprints.

In sub-aqueous environments, earthquake-related deposits are identified as rapidly deposited layers intercalated within a more continuously and slowly depositing sedimentary sequence. These layers usually have large extension and specific signatures related to a variety of earthquake-related sedimentary processes, such as: (i) liquefaction; (ii) triggered sub-aqueous slope destabilization and the related mass wasting flow forming a turbiditic deposit; (iii) seiche motion (e.g., oscillation of the water body), and induced resuspension of lake-bottom sediments [Beck 2009]; (iv) hydroplastic deformation induced by strong ground motion [Matsuda 2000]; and (v) changes in the lake watershed related to coseismic weakening of substrate material and associated landslides, which would trigger an increase in sediment delivery into the lake [Dadson et al. 2004].

Earthquake-related sedimentary changes have been characterized using a wealth of different proxies, like magnetic properties [Beck 2009, Larrasoana et al. 2010], grain size [Shiki et al. 2000, Bertrand et al. 2007], geochemistry [Carrillo et al. 2008, Schwab et al. 2009], paleontological indicators [Leroy et al. 2002, Hayward et al. 2005, Cochran et 


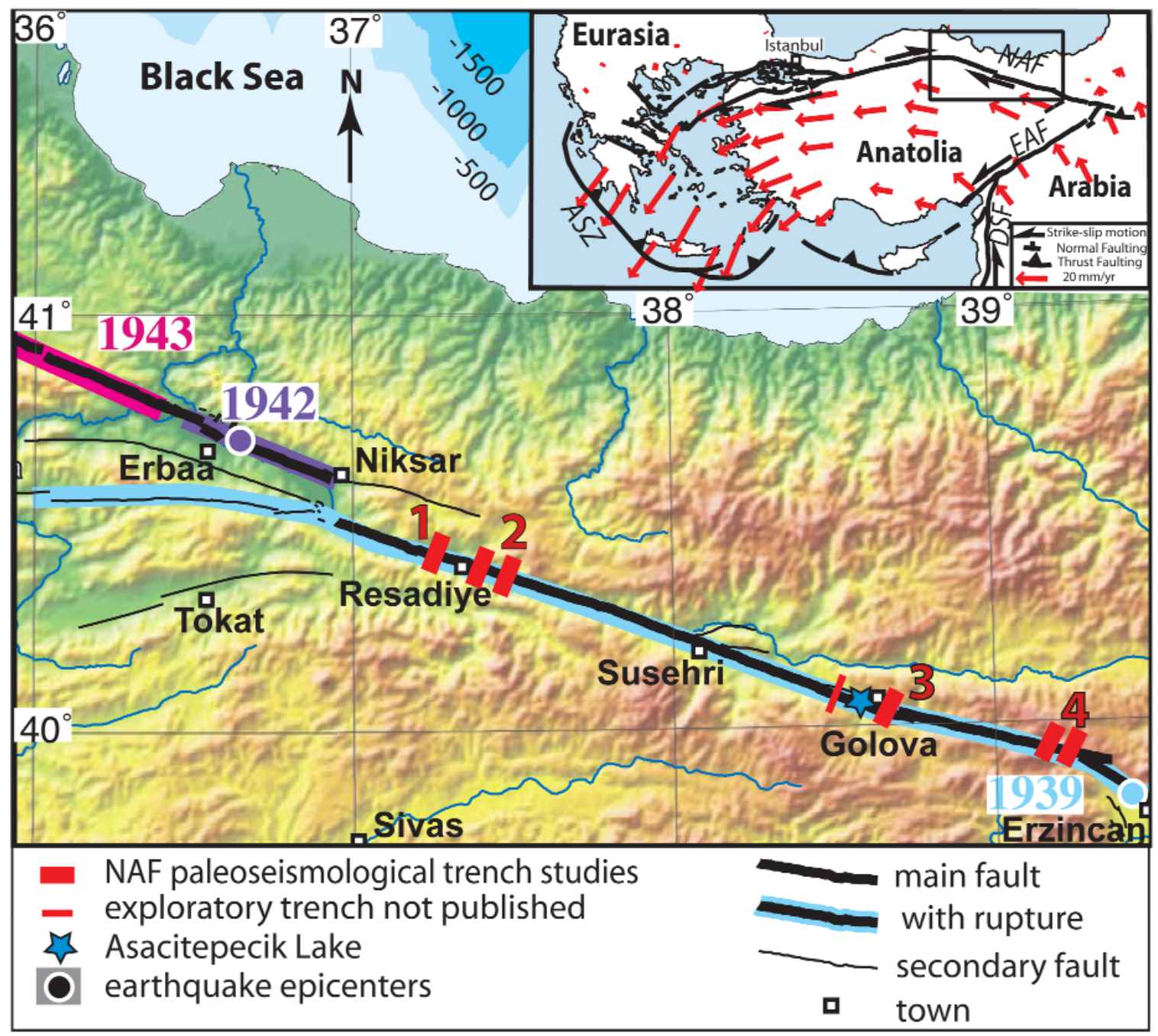

Figure 1. The eastern North Anatolian Fault and its paleoseismological record. 1, site of Fraser et al. [2010]; 2, site of Zabci et al. [2011]; 3, site of Fraser et al. (this volume); 4 site of Hartleb et al. [2006] and Kozac1 et al. [2011]. Different colors underlying the main fault trace show ruptures associated with the $1939 \mathrm{M}=7.9$ Erzincan earthquake (purple), the $1942 \mathrm{M}=7.1 \mathrm{Niksar-Erbaa}$ earthquake (blue), and the eastern part of the $1943 \mathrm{M}=7.3 \mathrm{Tosya}$ earthquake (pink). Our study focuses on the Aşağıtepecik Lake (AT Lake, blue star). Inset: Anatolian extrusion accommodated by the North Anatolian Fault (NAF) toward the Aegean Subduction Zone (ASZ), with GPS data from Reilinger et al. [2006] and the location of Figure 1.

al. 2007, Leroy et al. 2009, Schwab et al. 2009], and very high resolution seismic lines [Moernaut et al. 2007, 2009].

Most paleoseismological studies in lacustrine environments have focused on large lakes that are located in seismically active areas [e.g., Monecke et al. 2004, Moernaut et al. 2007, Marco and Agno 2005, Chapron et al. 1999], but not on the fault zone. In contrast, we present here the paleoseismological sedimentary record of a small and shallow pond, known as the A a 1tepecik Lake. This Lake occupies a small tectonic depression that is related to a minor releasing bend on a major strike-slip fault, the North Anatolian Fault (NAF). Our goal was to assess the usefulness of such shallow structural lakes for paleoseismological studies.

In the present study, the morphology of Aşağıtepecik Lake and the fault scarps related to the 1939 earthquake rupture are documented through combined sonar data and seismic data. The sedimentary infill of Aşağıtepecik Lake was sampled with sedimentary cores. Gradual and sudden textural and compositional changes in the retrieved sediments were studied with the combination of X-ray imagery, magnetic susceptibility, mineralogy, loss-on-ignition (LOI) analysis, X-ray-fluorescence (XRF) geochemistry, and carbon-nitrogen isotope analysis. The age of the sedimentary sequence was constrained by combining radiocarbon dating, previously published ${ }^{210} \mathrm{~Pb}^{137} \mathrm{C}$ data [Boes et al. 2009], and correlation with a reference paleoclimatic lacustrine record in central Turkey [Jones et al. 2006]. The Aşağıtepecik Lake archive shows gradual sedimentary changes related to water shallowing, which was linked to regional climatic changes. The cores also display sudden rapidly deposited events characterized in the present study. The possible link between sedimentary events and major historical earthquakes along the NAF is discussed.

\section{Tectonic and paleoseismological setting}

Our study focuses on the NAF, a major, 1500-km-long, right-lateral, strike-slip fault in Turkey. With the conjugate 


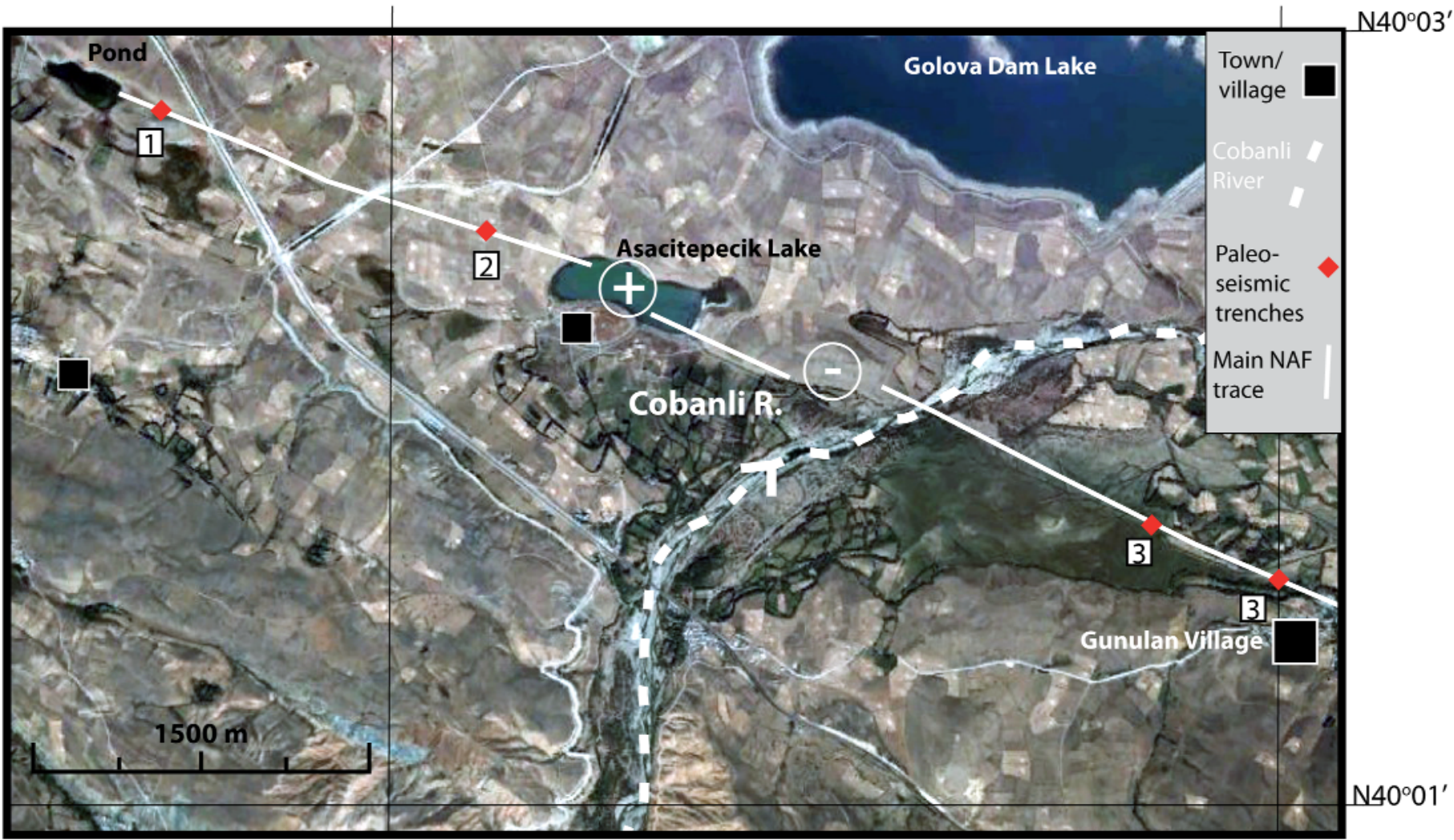

Figure 2. Relationships between Aşağıtepecik Lake and the NAF. The small depression filled by Aşağıtepecik Lake is located along a small releasing step. A minor restraining bend and the associated ridge are located to the SE of Aşağıtepecik Lake. Paleoseismological sites are indicated with red squares: 1 for Okomura et al. [1994]; 2 for Zabci et al. [2008]; 3 for Fraser et al. (this volume).

East Anatolian Fault, the NAF accommodates the westward motion of the Anatolian microplate away from the Arabia-Eurasia collision zone [Hubert-Ferrari et al. 2002, Reilinger et al. 2006] (see Figure 1, inset). Along the NAF, the geological and geodetic slip rates are similar (e.g., 20 to $25 \mathrm{~mm} / \mathrm{yr}$ ) [see Hubert-Ferrari et al. 2002, Kozac1 et al. 2007, Reilinger et al. 2006], which suggests a simple seismic cycle that is characterized by nearly equal stress loading and strain release along this fault. The rupture of the NAF over $900 \mathrm{~km}$ during the 20th century further supports this view. The rupture occurred in a westward propagating sequence of $M>7$ earthquakes [Ambraseys 1970, Barka 1992] that started in 1939 in the east with the $M=7.9$ Erzincan earthquake, and ended in the west with the 1999 İzmit and Düzce earthquakes [Stein et al. 1997, HubertFerrari et al. 2000]. The fault has also ruptured in sequence in the past [Ambraseys 1970, Ambraseys and Finkel 1988]. However the integrated history of earthquakes built using all of the paleoseismological data available along the NAF suggests variable recurrence times along the fault linked to different tectonic regimes in the Anatolian microplate [Fraser et al. 2010]. This latter implies a more complex seismic cycle than previously thought.

In this report we focus on the eastern NAF, which ruptured during the $1939 \mathrm{M}=7.9$ Erzincan earthquake between the towns of Erzincan and Niksar (Figure 1). Other large earthquakes took place along the eastern NAF in 1668, 1254, 1045 and 499 [Ambraseys 2009]. Historical records of these earthquakes are sparse and incomplete. Paleoseismic studies combined with historical data, as detailed below, allow a more accurate interpretation of the rupture extent. The damage related to the 1668 earthquake is not well documented in the east, with only the mention of some destruction in the towns of Erzincan and Tokat [Ambraseys and Finkel 1988]. The paleoseismic trenches labeled as 1 to 3 in Figure 1 [Fraser et al. 2010, Zabc1 et al. 2011, Fraser et al. this volume] document a fault rupture at that time, although paleoseismic studies further east did not document any major earthquakes from the 14th to 19th centuries (Figure 1, label 4; [Hartleb et al. 2006, Kozac1 et al. 2011]. For the 1254 earthquake, Ambraseys and Melville [1995] and Ambraseys and Jackson [1998] reported historical surface ruptures from Erzincan to Suşehri, and the paleoseismic trenches labeled 1 to 4 in Figure 1 document an earthquake during that time period. Damage in historical accounts related to the 1045 earthquake was centered on Erzincan, and trenches along the Erzincan segment (Figure 1, numbers 4 and 2) documented a paleoearthquake during that time period. In 499, the towns of Niksar (e.g., NeoCaesare) and Suşehri (e.g., Nicopolis) were greatly damaged, and important disturbances of the Euphratus River occurred near Erzincan 
[Ambraseys and Melville 1995, Guidoboni et al. 1994]. The 499 earthquake has been documented in all of the paleoseismic trenches along the eastern NAF. Paleoseismic data thus suggest a rupture pattern along the eastern NAF that might be irregular and different from the 1939 rupture [Fraser et al. 2010]. This sedimentological study of Aşağıtepecik Lake infill along the central eastern NAF segment sought to provide additional paleoseismological constraints within this framework.

\section{Site description}

\subsection{Local tectonics and paleoseismological records}

Aşağıtepecik Lake is located in the Gölova Basin. The deposits from this basin comprise Pliocene conglomerates, with some alternating shale and marl deposits that rest on a basement formed of different units [Koçyiğit 1990]. Along its northern margin, there are Permian-Triassic schists and marble outcrops, whereas the Ophiolitic Mélange of the Ankara-Erzincan Tethyan Suture and the associated tertiary clastic and carbonate sediments outcrop along its southern margin [Koçyiğit 1990].

The Gölova Basin is $3 \mathrm{~km}$ wide, $35 \mathrm{~km}$ long, and has a strike similar to the NAF. It is cross-cut by the N $110^{\circ}$ striking NAF and bordered by weakly active normal faults. In the central part of the basin, the apparent S-shape of the Cobanli River has been interpreted as a cumulated rightlateral offset of $7 \mathrm{~km}$ to $15 \mathrm{~km}$ along the NAF [Barka and Kadinsky-Cade 1988, Koçyiğit 1990]. The basin morphology is linked to the right-lateral motion along the NAF, which has been active since Mio-Pliocene times [Koçyiğit 1990]. We interpret the Gölova Basin as an evolved, crosscut, pull-apart basin that is similar to Hazar Lake along the East Anatolian Fault [Garcia-Moreno et al. 2010].

Across the basin, several small-scale structural complexities occur along the NAF segment. One of these is the small depression that is occupied by Aşağıtepecik Lake (Figure 2). The 1939 fault rupture mapped by Koçyiğit [1990] and Barka [1996] ran across Aşağıtepecik Lake, and a coseismic right-lateral slip of $6.5 \mathrm{~m}$ was deduced from the offset of field boundaries, a few $100 \mathrm{~m}$ west of Aşağıtepecik Lake.

Several paleoseismic trenches that crossed the NAF were excavated near Aşağıtepecik Lake (Figure 2). The trench of Zabci et al. [2008] was located just a few $100 \mathrm{~m}$ west of Aşağıtepecik Lake $\left(40.0402^{\circ} \mathrm{N} / 38.5800^{\circ} \mathrm{E}\right)$. Stratification and clear structural relationships indicated three events, including the 1939 Erzincan earthquake, but the ages of the determined paleo-events could not be constrained due to limited samples for radiocarbon dating (Zabci, personal communication). The exploratory trench of Okomura et al. [1994] $\left(40.046111^{\circ} \mathrm{N} / 38.562222^{\circ} \mathrm{E}\right)$ was located $2 \mathrm{~km}$ west of Aşağıtepecik Lake, but no information is available about the trench study. About $2 \mathrm{~km}$ to $4 \mathrm{~km}$ east of Aşağıtepecik Lake, Fraser et al. (this volume) opened a series of three trenches $\left(\mathrm{T} 1: 40.028226^{\circ} \mathrm{N} / 38.617813^{\circ} \mathrm{E}\right.$; $\mathrm{T} 2$ : $40.026173^{\circ} \mathrm{N} / 38.623918^{\circ} \mathrm{E}$; T3: $40.021265^{\circ} \mathrm{N} / 38.638594^{\circ} \mathrm{E}$ ). Their paleoseismic investigations defined the timing of six paleoearthquakes, with the first four corresponding to historical events (Event 0: 1939; Event 1: 1668; Event 2: 1254; Event 3: 499).

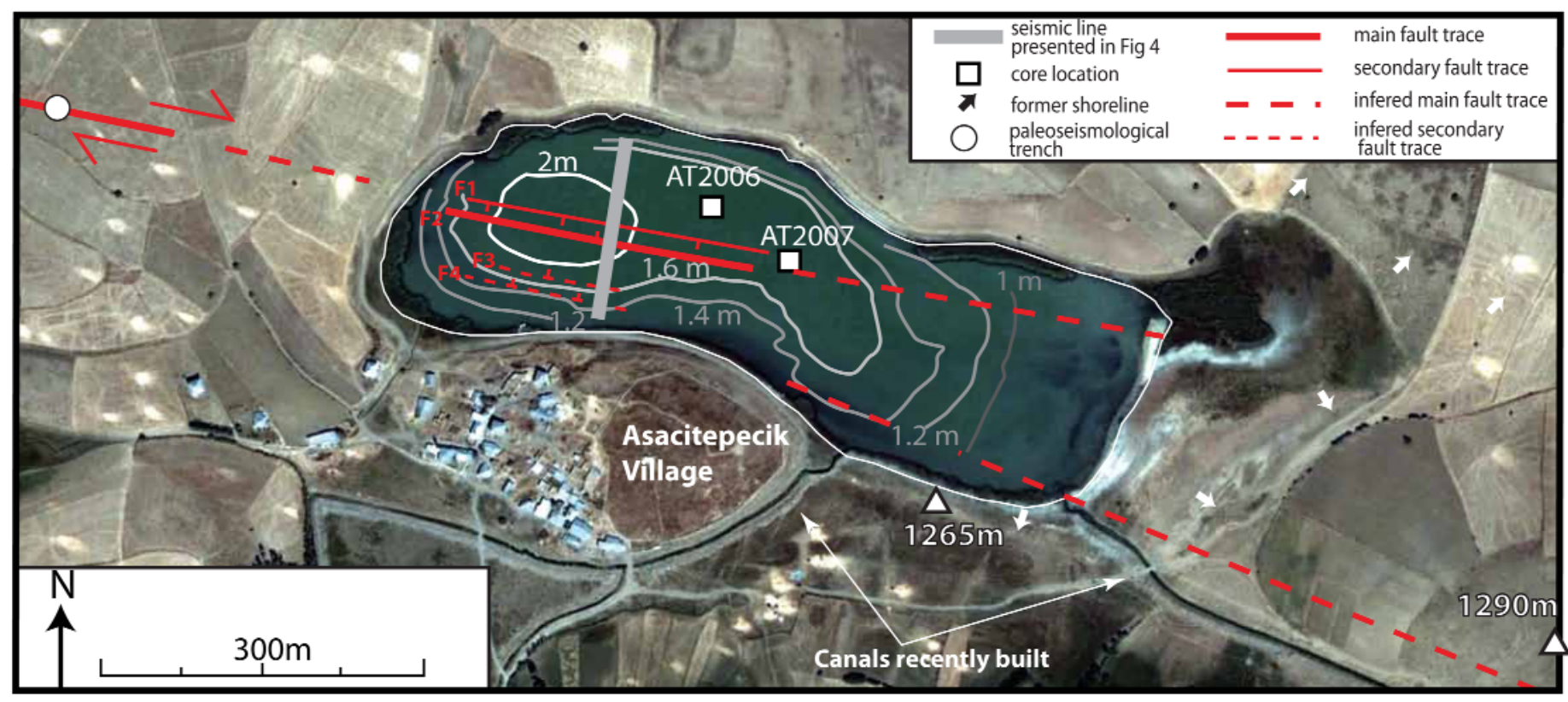

Figure 3. Bathymetry of Aşağıtepecik Lake and the core locations (squares). Continuous red lines indicate fault scarps visible in the seismic lines or in the paleoseismic trench of Zabci et al. [2008] (circle); dashed red lines indicate the inferred fault geometry. Different labels (F1, F2, F3 and F4) are used for the fault scarps identified in the seismic lines (see Figure 4). Lake bathymetry was measured in July 2006 with sonar GPS. The Așağitepecik village lies along the southern shore of the lake as well as water canals recently built after 2000 for irrigation purpose. The lake is in continuity with the flood-plain of the Cobali River (see Figure 2). 


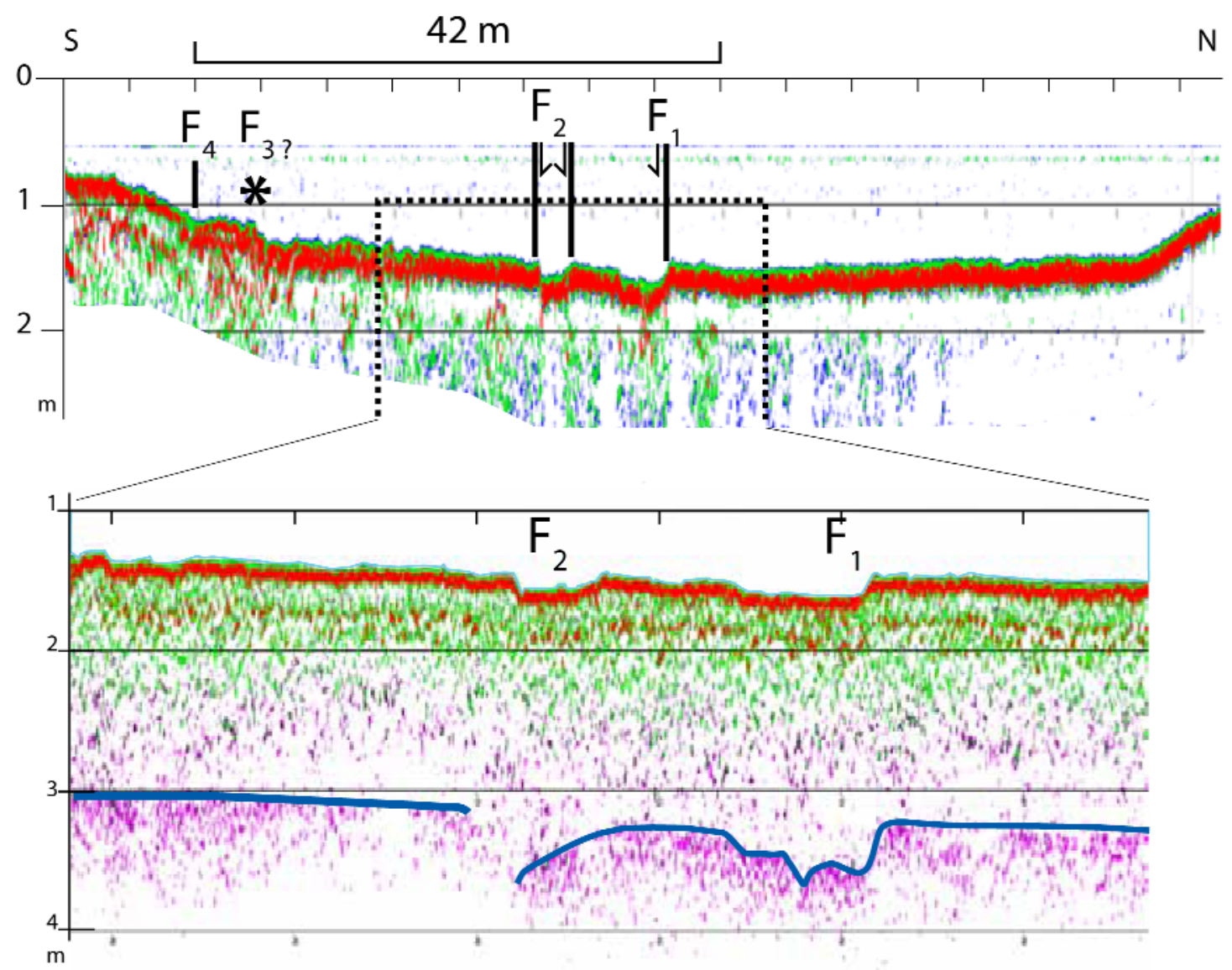

Figure 4. Typical seismic line across Aşağıtepecik Lake obtained using an Innomar Profiler. The upper panel shows the low frequency signal (6 to 12 $\mathrm{kHz}$ ), and the lower panel inset shows the high frequency signal $(100 \mathrm{kHz})$. Small fault scarps are still visible in the central part of Așağıtepecik Lake, and on its southern margin. The surface fault scarps are $10 \mathrm{~cm}$ to $20 \mathrm{~cm}$ high.

\subsection{Local geomorphology}

The geomorphology around Aşağitepecik Lake is shaped by the flow of the Çobanlı River and the rightlateral deformation along the NAF (Figure 2). To the south of the NAF, the northward flowing Çobanlı River forms a wide alluvial plain, but to the north, the river bends eastwards and has a narrow, meandering bed. Aşağıtepecik Lake is located just at the northward limit of the wide alluvial plain, about $700 \mathrm{~m}$ west from the present Çobanlı riverbed (Figure 2). An E-W-trending ridge that stands $25 \mathrm{~m}$ above the riverbed separates Aşağıtepecik Lake from the Çobanlı riverbed. This ridge and the depression occupied by Aşağıtepecik Lake are interpreted as related to minor structural discontinuities along the NAF (Figures 2, 3).

The tectonic depression occupied by Aşağıtepecik Lake is $700 \mathrm{~m}$ long, $200 \mathrm{~m}$ wide, and elongated along the NAF fault (Figure 3). It is surrounded by low hills with very gentle slopes. Aşağıtepecik Lake has a very restricted watershed, no river inflow, no natural outlet, and a shallow water depth. The lakeshores are covered with vegetation (e.g., Phragmites). On the eastern and northeastern edges of the lake, there are geomorphological indications of former higher paleoshorelines (Figure 3, white arrows). Along its southern edge, a small village occupies a local height, and man-made channels are used for irrigation. In particular, a water channel links the Aşağıtepecik Lake and the Çobanlı River. This channel has been recently renovated, but the original date of its construction is not known. All of the lands around Aşağıtepecik Lake are agricultural fields.

\subsection{Preliminary sedimentological study of Aşağttepecik Lake}

A preliminary sedimentological study of Aşağıtepecik Lake was conducted by Boes et al. [2009]. They studied a short core from Aşağıtepecik Lake, as well as four others from other lakes along the NAF. In all of these cores, the sedimentological fingerprints of the 20th century earthquake sequence were identified using excess ${ }^{210} \mathrm{~Pb}$ and ${ }^{137} \mathrm{Cs}$ measurements. In Aşağıtepecik Lake, the sedimentary disturbance associated with the $\mathrm{M}=7.91939$ earthquake was identified at depths between $10 \mathrm{~cm}$ and $55 \mathrm{~cm}$, and possibly down to $99 \mathrm{~cm}$; in addition, a mean sedimentation rate of $1.5 \mathrm{~mm} / \mathrm{yr}$ over the last $70 \mathrm{yr}$ was inferred 
[Boes et al. 2009]. The study of Boes et al. [2009] concludes that Aşağıtepecik Lake has recorded past major earthquake ruptures of the NAF.

\section{Materials and methods}

\subsection{Bathymetry, geophysics and coring}

We produced a bathymetric map of the lake in 2006, using Garmin global positioning system (GPS) map 178 equipped with sonar (Figure 3). In addition to clarifying the interplay between the NAF structure and the lacustrine sedimentation, eight single-channel seismic reflection profiles were acquired in 2007, with an Innomar SES2000-Compact Sub-bottom Profiler (ITU-EMCOL Equipment) in the deepest western part of Aşağıtepecik Lake. Both the primary high frequency signals $(100 \mathrm{kHz})$ and the secondary low frequency signals (6 to $12 \mathrm{kHz}$ ) were recorded (Figure 4). The penetration reached $50 \mathrm{~cm}$ to $100 \mathrm{~cm}$ using the low frequency signal, and $100 \mathrm{~cm}$ to $300 \mathrm{~cm}$ using the high frequency signal.

Sedimentary cores were collected in 2006 and 2007, within the framework of the Seismic Cycle Project [Hubert-Ferrari et al. 2007] (Figure 3). In 2006, the 1.2-m-long short core labeled as "AT2006" and partly studied in Boes et al. [2009], was retrieved from the central part of Aşağıtepecik Lake $\left(40.03924^{\circ} \mathrm{N} / 38.58752^{\circ} \mathrm{E}\right)$ using a modified UWITEC gravity corer. In 2007, we collected a 2.5 -m-long piston core, labeled as "AT2007LG", and an associated 1-m-long gravity core, labeled as "AT2007", at the same site $\left(40.03876^{\circ} \mathrm{N} / 38.58836^{\circ} \mathrm{E}\right)$. The AT2007 site is located very near the main fault, and it has shallower water than at the AT2006 site. The present study is based on the analysis of all of these cores, with a special focus on the longest core, AT2007LG.

\subsection{Sediment analysis}

Different types of analysis were performed on the cores to characterize the background continuous sedimentation and potential rapidly deposited layers related to earthquakes. We first carried out a detailed visual stratigraphic log of all of the cores (somewhat similar to conventional paleoseismic trench logging). The log was complemented by smear slides of the different sedimentary fractions $(>450 \mu \mathrm{m}, 450-250 \mu \mathrm{m}$, $250-100 \mu \mathrm{m})$. The stratigraphy and microstructures were further investigated using X-ray imagery on the AT2007LG core (SCOPIX system, EPOC Bordeaux I, France) [see Migeon et al. 1999], and the textural properties were examined with individual granulometric analysis of the AT2007 core (Malvern Mastersizer). Before grain-size measurements, the organic matter was digested using hot $\mathrm{H}_{2} \mathrm{O}_{2}$.

Sedimentological changes recorded in Aşağıtepecik Lake were further probed using magnetic susceptibility data, which was acquired on all of the cores at $5-\mathrm{mm}$ resolution, using the Geotek multi-sensor core logger of Rhodes Island University (USA). The magnetic susceptibility data and the macroscopic descriptions were used to correlate the different cores (Figure 5). To constrain compositional changes, we performed bulk mineralogy analyses using X-ray diffraction (XRD) on 80 samples of the AT2007LG core.

To investigate water level changes in relation to regional climate changes, we investigated the organic matter changes related to Phragmites growing along the shoreline, and to Charophyte algae. With the AT2007LG core, we combined LOI data (4 h at $550{ }^{\circ} \mathrm{C}$; 135 measurements) with measurements of total organic carbon (TOC), carbon/ nitrogen $(\mathrm{C} / \mathrm{N})$ ratios, carbon and nitrogen stable isotopes (60 samples treated with $\mathrm{HCl}$ to removed all mineral carbonates before the analysis). The $\mathrm{C} / \mathrm{N}, \delta^{13} \mathrm{C}_{\text {org }}$ and $\delta^{15} \mathrm{~N}$ data provide information regarding the origin of the organic matter and the lake productivity [e.g., Meyers and Teranes 2001, Bertrand et al. 2009]. The organic matter in Aşağıtepecik Lake is essentially a mixture of organic matter that was produced in the lake, comprising algae, including Charophytes, Phragmites and potentially cyanobacteria. Phragmites have a $\delta^{13} \mathrm{C}_{\text {org }}$ of about -26 [Wainright et al. 2000]. Organic matter produced by algae ( $\mathrm{C} 3$ plants) using dissolved $\mathrm{CO}_{2}$ in isotopic equilibrium with the atmosphere is usually isotopically indistinguishable from organic matter produced by $\mathrm{C} 3$ plants on land and on lake margins. The algae $\delta^{13} \mathrm{C}_{\text {org }}$ values were, however, sensitive to changes in the lake primary productivity, and they were also distinctly more negative than the organic matter produced by $\mathrm{C} 4$ land plants [Sifeddine et al. 2011]. Cyanobacteria showed high values of $\delta^{13} \mathrm{C}_{\text {org }}$. For the $\mathrm{C} / \mathrm{N}$ ratio, Phragmites have a $\mathrm{C} / \mathrm{N}$ ratio of $12-13$, and smaller values in brackish environments [Wainright et al. 2000, Farnsworth and Meyerson 2003]. Lake plankton have a C/N ratio generally around 10 , but this varies with nutrient availability and with species-specific characteristics [Sterner and Elser 2002]. Finally, the $\delta^{15} \mathrm{~N}$ is particularly useful to identify organic matter sources. The $\delta^{15} \mathrm{~N}$ values are different for algae and aquatic plants at lake edges, because most algae use dissolved $\mathrm{NO}_{3}$ and have large $\delta^{15} \mathrm{~N}$ values, whereas land plants and aquatic plants use atmospheric $\mathrm{N}_{2}$ and have lower $\delta^{15} \mathrm{~N}$ values. Phragmites have $\delta^{15} \mathrm{~N}$ values of 9 to 10 [Wainright et al. 2000], and algae of 4 to 9 [Sifeddine et al. 2011]. Atmospheric $\mathrm{N}_{2}$-fixing cyanobacteria typically have $\delta^{15} \mathrm{~N}=0$ \pm 2 ; [Fogel and Cifuentes 1993, Talbot and Laerdal 2000].

Finally, to better decipher the origins of the sedimentary changes in the cores, measurements of the major elements ( $\mathrm{Al}, \mathrm{Si}, \mathrm{S}, \mathrm{Cl}, \mathrm{K}, \mathrm{Ca}, \mathrm{Ti}, \mathrm{Mn}, \mathrm{Fe}, \mathrm{Rh}$ ) were undertaken on the AT2007LG core using XRF at $0.5-\mathrm{cm}$ resolution $(10 \mathrm{kV}, 2-\mathrm{mm}$ spacing on the Avaatech core scanner of EPOC Bordeaux I, France). XRF core-scanner data are only semi-quantitative measurements of element abundance [Croudace et al. 2006, Richter et al. 2006, Rothwell and Rack 2006], because of variable water content, grain-size distribution, inhomogeneities of the specimens, and the irregular scanned surface of a core. In addition, XRF scanners are largely insensitive to organic 

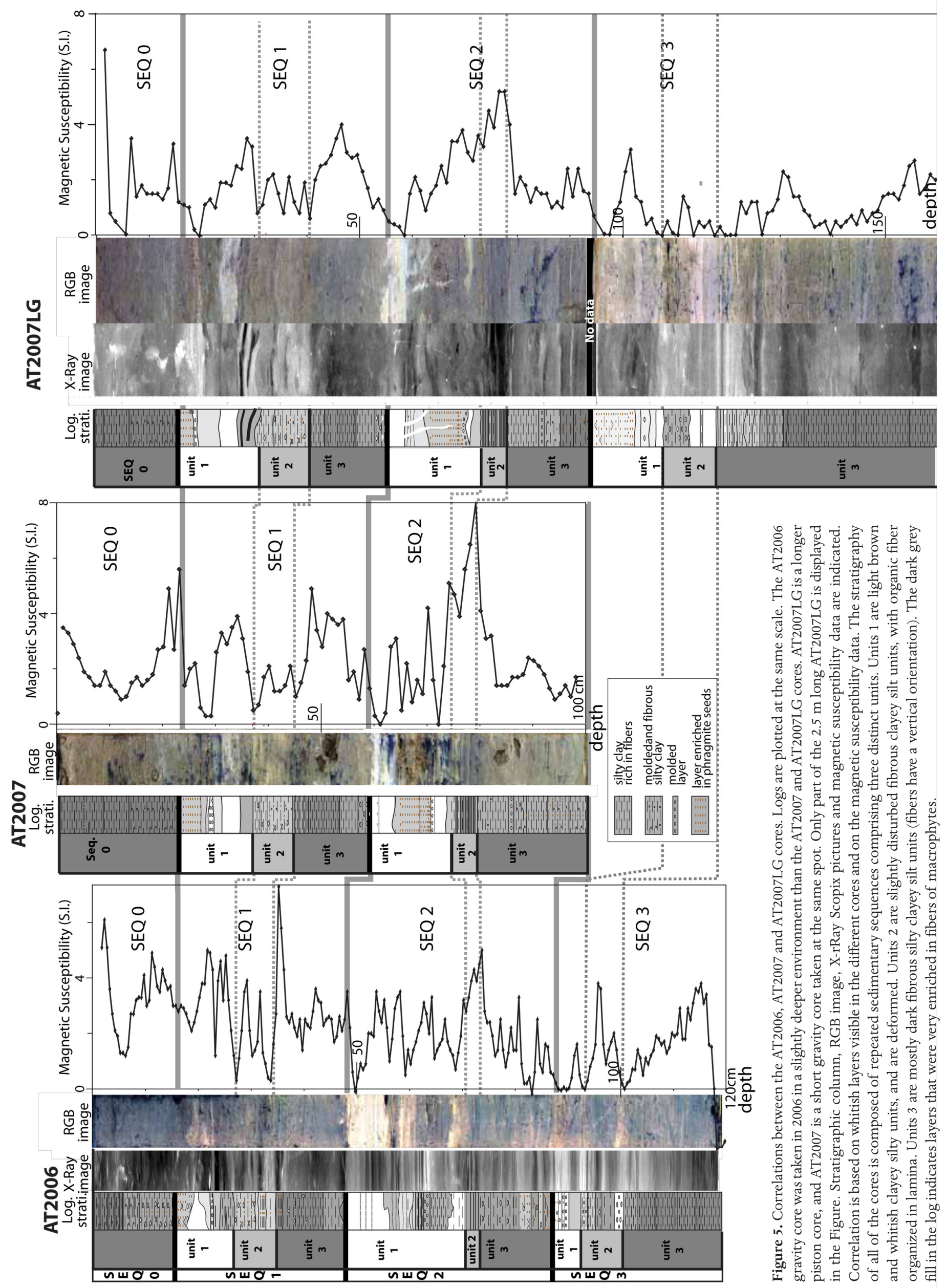

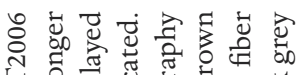

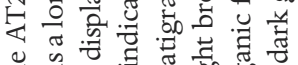

F.

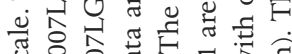

议 \& व

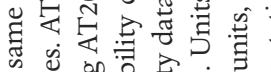

空

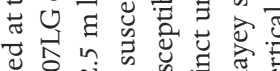

过 $\hat{0}$ i

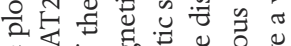

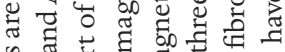

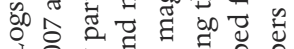

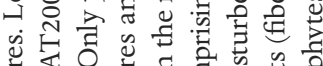

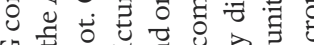

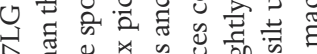

今。

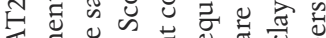

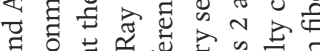

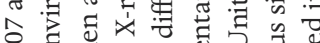

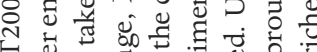

\&

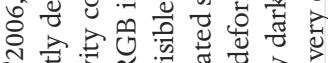

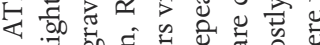

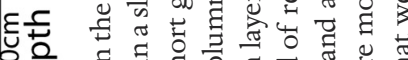

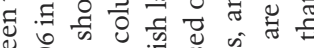

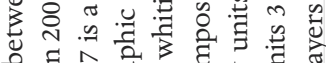

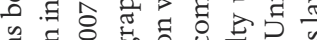

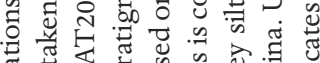

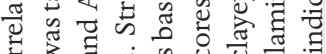

ठำ

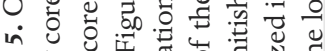

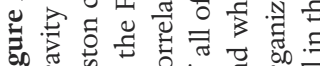


materials in the sediment, but high levels of organic material dilute the measured components [Lowemark et al. 2011]. Some of these problems can be overcome using ratios of elements, which are thus considered as more reliable proxies [e.g., Weltje and Tjallingii 2008]. Normalization is usually carried out against a conservative element, to allow changes in the input of the elements to be addressed. Aluminium is often chosen to obtain an environmentally relevant signal [Lowemark et al. 2011]. As Al is poorly detected, Ti was also considered here. Ti shows less scatter, is abundant in many minerals, and biologically it is not very active. Here we present $\mathrm{Ti}$ and $\mathrm{Fe}$ counts data, as well as $\mathrm{Fe} / \mathrm{Al}$ and $\mathrm{Ca} / \mathrm{Ti}$ ratios, which we compare with other analyses. Normalization with $\mathrm{Al}$ allows the relative variations in the lithogenic components of the sediment to be addressed. The $\mathrm{Ca} / \mathrm{Ti}$ ratio is a proxy that can represent the lake biogenic productivity with respect to allogenic terrigenous input [e.g., Drab et al. 2012]. The $\mathrm{Ca} /$ Ti record obtained was also compared with a varved reference record in central Turkey [Jones et al. 2006].

\subsection{Dating}

The age of the sedimentary record was constrained using accelerator mass spectrometry radiocarbon dating (Table 1). Nine bulk samples were first selected. Given the poor results, the AT2007LG core was sieved to find other types of organic material. Terrestrial seeds were found in three intervals and they were dated. We also collected eggs of daphnids, a tiny crustacean, called Ephippia, of Daphnia, in the $>450-\mathrm{mm}$ fraction at three different intervals. Radiocarbon dating was carried out on the samples with 150 to 200
Ephippia. Our goal was to test the reliability of this type of material for constraining the age of lacustrine sediments. Finally the core was correlated to the annually laminated sequence from the Nar Lake in central Turkey [Jones et al. 2006]. The $d^{18} \mathrm{O}$ record of the Nar Lake shows a high-resolution record of precipitation and evaporation variability over the past $1700 \mathrm{yr}$.

\section{Results}

\subsection{Local fault structure in and around Aşağitepecik Lake}

The bathymetry map in Figure 3 shows that Aşağıtepecik Lake is very shallow, reaching a maximum water depth of about $2 \mathrm{~m}$. The depression occupied by Aşağıtepecik Lake is divided into two parts: a shallow marsh in the east, and a deeper basin in the west. The deeper basin lies north of Assağıtepecik village, in straight continuity with the main fault that was exposed in the paleoseismological trench of Zabci et al. [2008].

The fault geometry shown in Figure 3 was constrained, combining seismic profiles, field work, and paleoseismological trench location. Aşağıtepecik Lake is a pull-apart that is bounded by fault segments with a separation of about $150 \mathrm{~m}$ and a local change in the strike of a few degrees. The seismic profiles provide further details about the fault geometry in the deep basin. The seismic quality is rather poor, probably because the organic-rich sediments of Aşağıtepecik Lake are degraded and were converted to methane. The gascharged sediments, as well as multiple interference, prevented any deep imaging (Figure 4). The profiles imaged the

\begin{tabular}{|c|c|c|c|c|c|c|c|c|c|c|}
\hline Label & $\begin{array}{c}\text { Depth } \\
(\mathrm{cm})\end{array}$ & $\begin{array}{l}\text { Width } \\
\text { (cm) }\end{array}$ & Description & $\begin{array}{l}\text { Yield } \\
(\%)\end{array}$ & $\mathrm{mg}$ & $\delta^{13} \mathrm{C}$ & Fc & \pm & ${ }^{14} \mathrm{C}$ age & \pm \\
\hline AT2007/01 0-100 36-37 & 36.5 & 0.5 & Bulk sediment & 3.8 & 1.09 & -27.3 & 0.7249 & 0.0038 & 2580 & 40 \\
\hline AT2007/01 0-100 56-57 & 56.5 & 0.5 & Bulk sediment & 3.7 & 1.17 & -30.5 & 0.6922 & 0.0026 & 2960 & 30 \\
\hline AT2007/01 0-100 80-81 & 80.5 & 0.5 & Bulk sediment & 5.0 & 1.32 & -26.9 & 0.7723 & 0.0037 & 2080 & 40 \\
\hline AT2007/01 100-200 33-34 & 133.5 & 0.5 & Bulk sediment & 5.9 & 1.08 & -23.5 & 0.7834 & 0.0028 & 1960 & 30 \\
\hline AT2007/01 100-200 85-86 & 185.5 & 0.5 & Bulk sediment & 4.7 & 1.27 & -25.8 & 0.7278 & 0.0038 & 2550 & 40 \\
\hline AT2007/01 200-260 3-4 & 203.5 & 0.5 & Bulk sediment & 5.6 & 1.22 & -25.2 & 0.7944 & 0.0034 & 1850 & 30 \\
\hline AT2007/ 01 200-260 22-23 & 222.5 & 0.5 & Bulk sediment & 6.2 & 1.04 & -24.1 & 0.7546 & 0.0027 & 2260 & 30 \\
\hline AT $2007(100-200 \mathrm{~cm}) 10-14$ & 112 & 2 & 2 terrestrial seeds & 44.5 & 1.061 & -10.1 & 0.8665 & 0.0018 & 1150 & 15 \\
\hline AT $2007(100-200 \mathrm{~cm}) 55-60$ & 157.5 & 2.5 & 192 Ephippia of Daphnia & 41.0 & 0.300 & -19.6 & 0.8650 & 0.0017 & 1165 & 15 \\
\hline AT $2007(100-200 \mathrm{~cm}) 80-95$ & 187.5 & 7.5 & 245 Ephippia of Daphnia & 41.3 & 0.395 & -20.1 & 0.8745 & 0.0016 & 1075 & 20 \\
\hline AT $2007(200-260 \mathrm{~cm}) 6-17$ & 211.5 & 5.5 & 2 terrestrial seeds & 42.6 & 1.061 & -12.1 & 0.8935 & 0.0020 & 905 & 15 \\
\hline AT $2007(200-260 \mathrm{~cm}) 28-35$ & 231.5 & 3.5 & 3 terrestrial seeds & 53.4 & 1.207 & -10.8 & 0.8988 & 0.0170 & 855 & 15 \\
\hline AT $2007(200-260 \mathrm{~cm}) 28-48$ & 238 & 10 & 240 Ephippia of Daphnia & 17.4 & 0.231 & -20.6 & 0.8797 & 0.0016 & 1030 & 15 \\
\hline
\end{tabular}

Table 1. Radiocarbon ages from the AT2007LG core. 

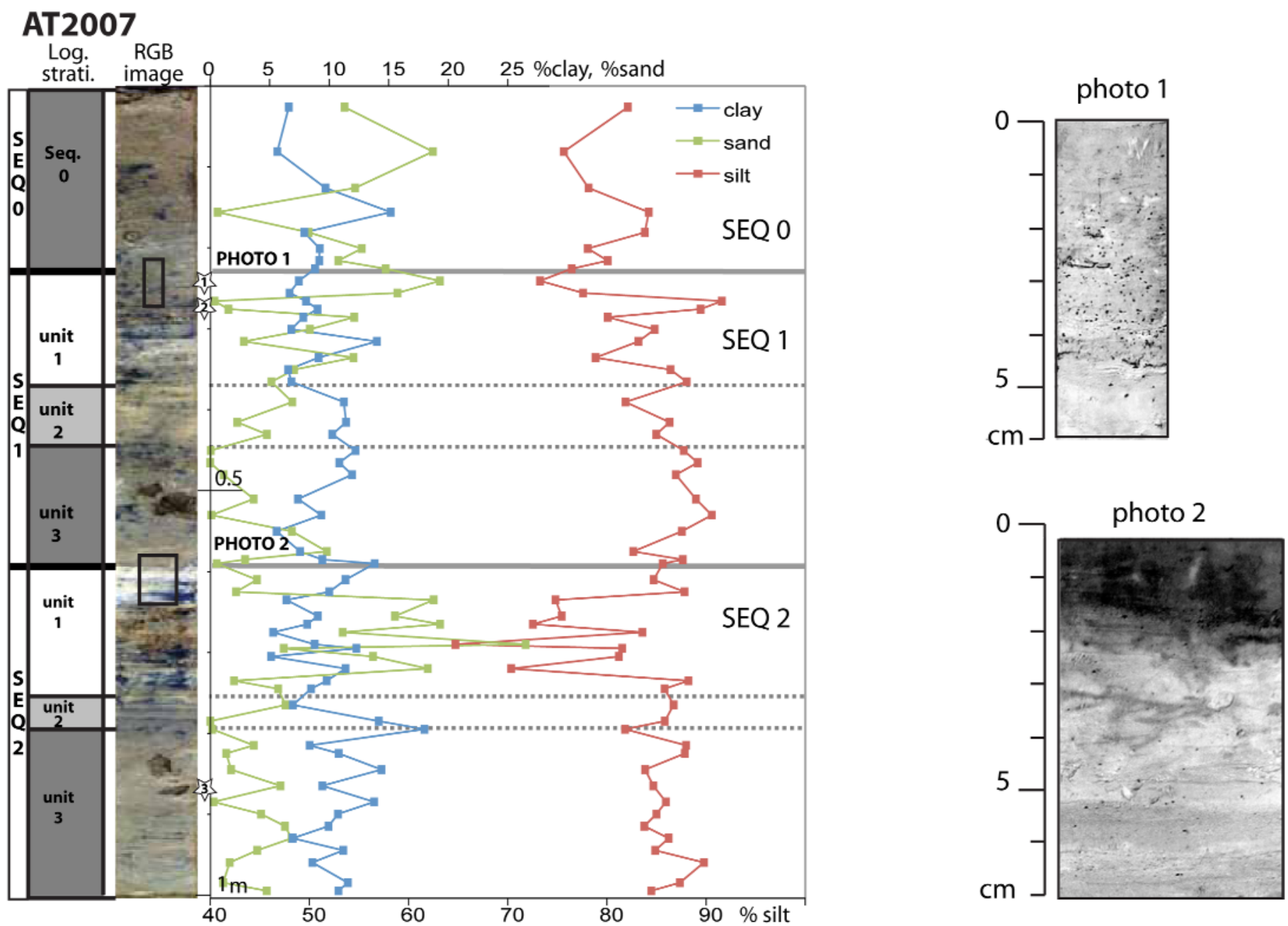

Figure 6. Granulometry of core AT2007. Left: stratigraphic log; right: percentage of clay, silt, and sand particles. Photos of the top of units 1 in sequences 1 and 2 are shown on the right, with their vertical scale. Stars indicate location of sieved samples in Figure 7.

subaqueous morphology perfectly, and showed a steep northern slope, a more gentle southern slope, a nearly flat depression in between, and several scarps (Figure 4). Two main fault scarps $(>10 \mathrm{~cm})$, labeled as "F1-F2", offset the flat depression. The F1-F2 fault system is in straight continuity with the on-land fault that was trenched by Zabci et al. [2008], and it can be interpreted as the principal displacement zone across Aşağıtepecik Lake. Other minor scarps $(\leq 10 \mathrm{~cm})$, labeled as F3 and F4, also affect the southern slope. All of the scarps can be consistently followed in the different profiles. The F1 scarp always shows a downthrown block to the south, which is consistent with a normal component on this fault, and the F2 scarp shows variable geometries that are consistent with strike-slip faulting. The imaged fault structure suggests slip partitioning with the right-lateral motion on a central fault, F2, normal faulting mostly centered on F1, and probably normal faulting on F3 and F4 to the south of the F1-F2 fault system.

\subsection{Core sediment characteristics}

The main results of the multi-proxy analyses are presented in Figures 5, 6, 7, 8, 9, 10 and 12.
5.2.1. Stratigraphy and core correlation based on magnetic susceptibility measurements and X-ray imagery

The three cores, AT2006, AT2007 and AT2007LG, showed organic-rich sedimentation (Figure 5). The magnetic susceptibility values of the sediments are generally low $(<5)$, which corresponds to the range of paramagnetic material expected in carbonate and organic-rich sediments. The stratigraphy of the three cores was similar. The tops of all of the cores showed dark-brown fibrous sediments, which were relatively homogeneous, with thicknesses ranging from $16 \mathrm{~cm}$ to $23 \mathrm{~cm}$. We labeled this top sequence 0 . Below, there were several sedimentary sequences, comprising at the top, a lighter brown to whitish clayey silty layer, and at the bottom, a dark brown fibrous organic-rich layer similar to the top sediment. There were two sequences in AT2007, three in AT2006, and four in AT2007LG. Individual sequences can be correlated between the different cores because they have similar visual and magnetic susceptibility characteristics. Each sequence was further subdivided in three sedimentary units, labeled 1 to 3 . This subdivision was based on differences in: (1) natural and X-Ray gray-scale color; (2) apparent textural organization of their organic con- 


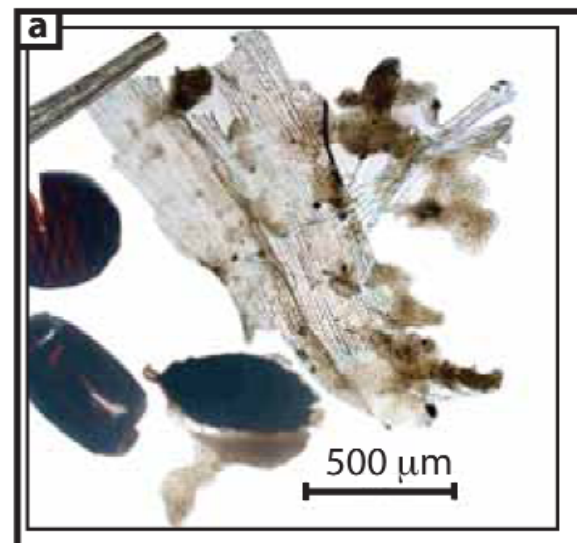

Fraction $>450 \mu \mathrm{m}$

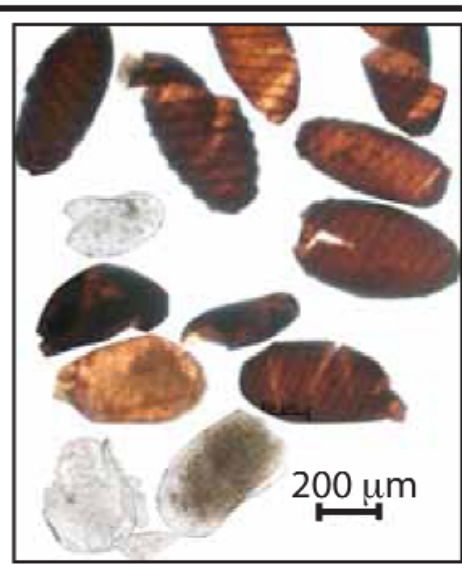

Fraction 250-450 $\mu \mathrm{m}$

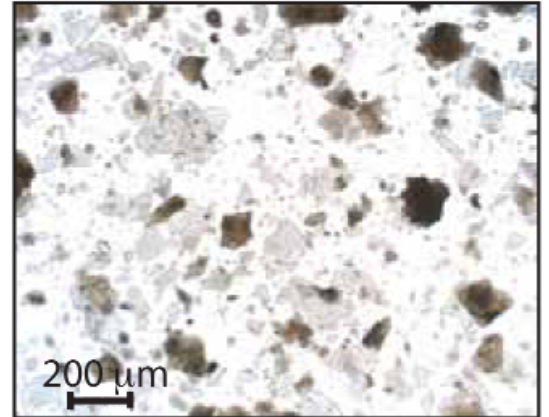

Fraction 100-250 um
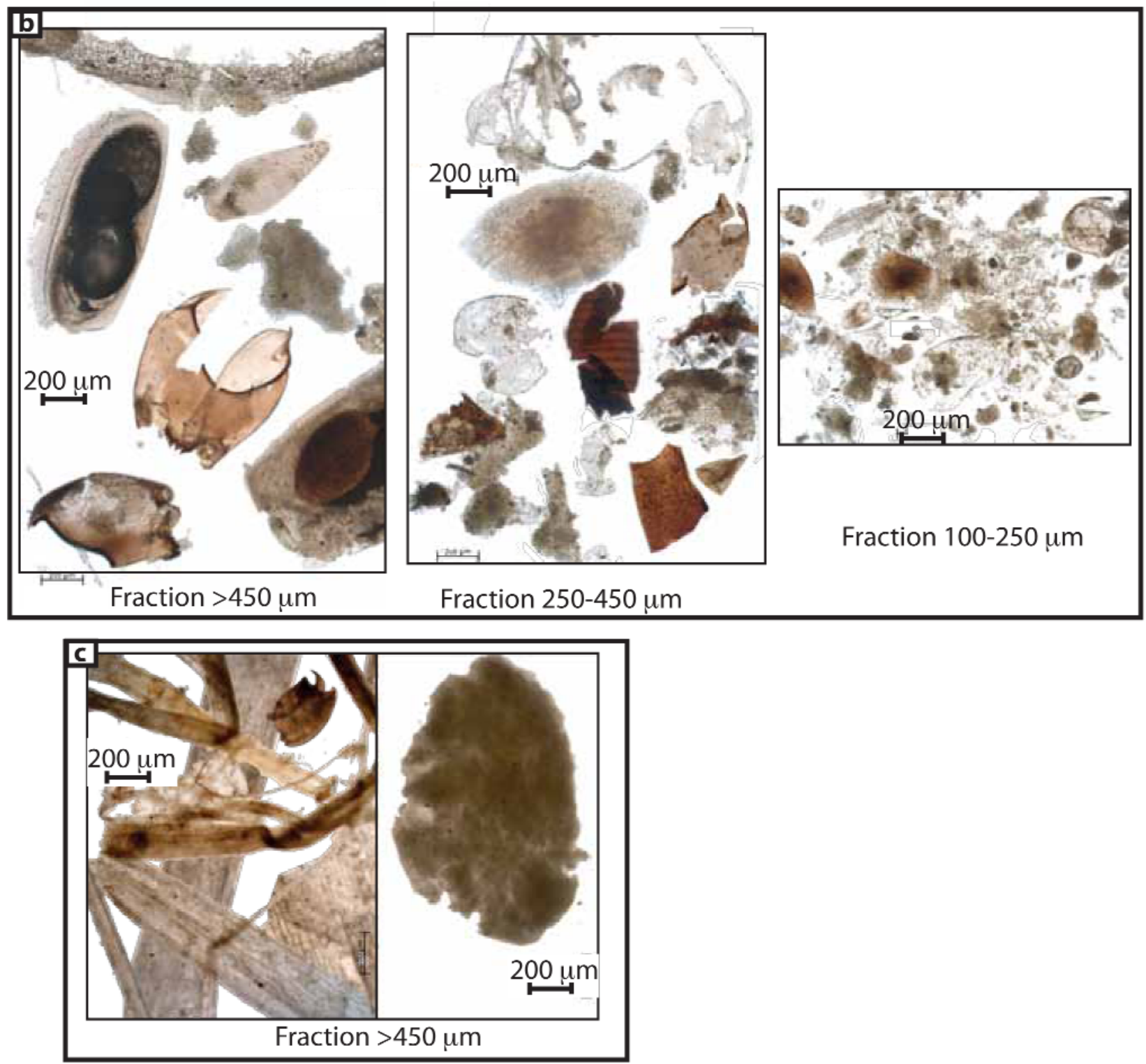

Figure 7. Content of core AT2007: photographs of the different sedimentary fractions after wet sieving; fractions sampled are indicated with a star in Figure 6. a: Sample at the top of unit 1-seq. 1 layer. The fraction $>450 \mu \mathrm{m}$ is secondary and contains a few large seeds and phytoclasts; the main $250 \mu \mathrm{m}$ to $450 \mu \mathrm{m}$ fraction shows an abundance of ostracods and non-calcified Charophyte seeds (oospores); the $100 \mu \mathrm{m}$ to $250 \mu \mathrm{m}$ fraction shows mostly broken ostracods, with some amorphous silty-clay aggregates. b: Sample in a lamina of unit 1-seq.1. The fraction of the $>450 \mu \mathrm{m}$ is more abundant, with a lot of Ephippia of Daphnia, seeds, some chironomids, different types of plant remains; the $250 \mu \mathrm{m}$ to $450 \mu \mathrm{m}$ fraction shows a mixture of broken ostracod shells, chironomids, seeds, phytoclasts, amorphous silty-clay aggregates; the $100 \mu \mathrm{m}$ to $250 \mu \mathrm{m}$ fraction shows broken ostracoda but in lesser amounts than above, and amorphous silty-clay aggregates. c: Sample in unit 3-seq.2. The sediment is dominated by the $>450 \mu \mathrm{m}$ fraction, composed of various organic fibers, probably including Phragmites and Charophytes remains (right) and silty-clay aggregates (left). 
tent; and (3) structural characteristics (e.g., disturbance, lamination). A detailed description of each unit is given below. This relies mostly on the long core, AT2007LG, for which we have a high quality X-ray image.

The bottom unit 3 was a fibrous, dark-colored, clayey silt unit that is similar to the topmost unit (sequence 0 ), with a rare mineral fraction. It showed variable thickness, ranging from $15 \mathrm{~cm}$ in sequence 1 , to $75 \mathrm{~cm}$ in sequence 3. Visual inspection showed a general homogeneity, with some gradual changes. The X-ray pictures for AT2007LG are generally dark and homogeneous, which suggested an opaque and dense material. The unit was composed of fibrous plants, which were mostly intact, including a high proportion of Charophyte algae (Figure 7c). The macrophyte fibers formed a closed-spaced net filled with silt and clay. In most of the AT2007 cores (Figures 5, 8), these fibers were generally oriented perpendicular to the water-sediment interface, implying in-place growth at shallow water depths and progressive sedimentary burial. In AT2006 and at the bottom of AT2007LG, fibrous materials were organized in lamina, and the sedimentation was characterized by alternating dark organic-rich lamina and light lamina [Boes et al. 2009]. This difference reflects the deeper water range at the AT2006 site than at the AT2007 site.

The top unit 1 in all of the sequences was a light colored, clayey silt unit with a coarser fraction composed of organic materials mixed with ostracod shells (Figures 5, 7a). This showed similar thicknesses, at around $15 \mathrm{~cm}$ in AT2007LG. At the top of the unit, the magnetic susceptibility measurements were particularly low, indicating an enrichment of carbonate and organic matter. The main characteristic of unit 1 was its heterogeneity, with repeated marked stratigraphic variations associated with structural disturbances. All of the units 1 showed whitish layers that formed key stratigraphic markers that were identifiable in the different cores. The different units 1 showed some differences.

Unit 1 in sequence 1 (unit 1-seq.1) was strongly disturbed and showed similar characteristics in all of the cores. Its top was structureless, enriched in small black seeds of Charophyte (gyrogonites), Phragmite seeds (Figure 6), and in whitish clay aggregates. It overlaid the whitish layer. Below minor injection structures were recognized in AT2007LG (Figure 5). In AT2006, the whitish layer was deformed, which suggested hydroplastic deformation. Finally, the bottom of unit 1 in AT2007LG showed strongly contrasted flaser bedding-like structures, which indicates that a shearing deformation occurred.

Unit 1 in sequence 2 (unit 1-seq.2) was as disturbed as unit 1-seq.1 and showed discontinuous, convex lamina, and small-scale funnel-shaped intrusions (see Figure 5: X-ray of AT2007). In AT2007LG the whitish layer at the top rested on a sublayer enriched in Charophytes seeds. The bottom was structureless and showed strong mixing. In AT2006, shearing was visible at the bottom of the whitish layer (Figure 5).

Unit 1 in sequence 3 (unit 1-seq.3) was not as strongly disturbed as the other units 1 . The top whitish layer was enriched in seeds and showed little structure in AT2007LG. The unit was not deformed in AT2006.

Unit 1 in sequence 4 (unit 1-seq.4) was whitish and very strongly disturbed (Figure 8), as it was completely structureless with no lamina (Figure 12). It looks like a homogenized layer that resulted from strong mixing. The concentration in Charophytes seeds was high and increased upwards. Its bottom showed dragged structures.

The middle unit 2 in all of the sequences in core AT2007LG showed a gradual transition between units 1 and 3 , and similar thicknesses ranging from $3.5 \mathrm{~cm}$ to $10 \mathrm{~cm}$ (Figures 5,8$)$. The color and visual characteristics of unit 2 were intermediate between units 1 and 3 . Unit 2 was usually rich in organic fibers, like unit 3 , but the fibers were organized in lamina with wavy contacts, unequal thicknesses and deformation, especially in sequences 1 and 2.

\subsubsection{Grain size}

The grain size of the mineral fraction analyzed in AT2007 comprised on average $85 \%$ silt, $10 \%$ clay, $5 \%$ sand particles (Figure 6). A significant part of the sand and silt particles were composed of clay aggregates and ostracods. The grain size distribution showed significant variations. A marked global increase in grain size occurred in units 1 of sequences 1 and 2 . In all units 1 , we also identify small-scale, grain-sized variations that were related to the different lamina that formed the unit. In addition, the maximum grain size did not occur at exactly the same location in sequences 1 and 2 . In sequence 1 , a maximum of sand-sized particles was reached at the topmost part of unit 1 , with a maximum in the clay-size particles above. In sequence 2 , the maximum grain size was reached in the middle of the unit, and the proportion of the sand-sized particles decreases sharply in the top whitish sublayer, and the clay reached a local maximum.

\subsubsection{Mineralogy}

The sediments had an particular mineralogy, which is summarized below, giving mean values with the minima and maxima (Figure 8). The minerals identified included quartz (mean: 5\%; minimum: $1 \%$; maximum: $9 \%$ ), calcite with a significant fraction of high-Mg calcite $(7 \% ; 2 \% ; 11 \%$; respectively), dolomite $(7 \% ; 4 \% ; 10 \%$; respectively), clay $(51 \% ; 41 \%$; $70 \%$; respectively), plagioclase (5\%; $0 \% ; 17 \%$; respectively), hematite $(4 \% ; 0 \% ; 9 \%$; respectively), goethite $(13 \% ; 0 \%$; $22 \%$; respectively), and hydromagnesite $(5 \% ; 0 \%$; $13 \%$; re- 


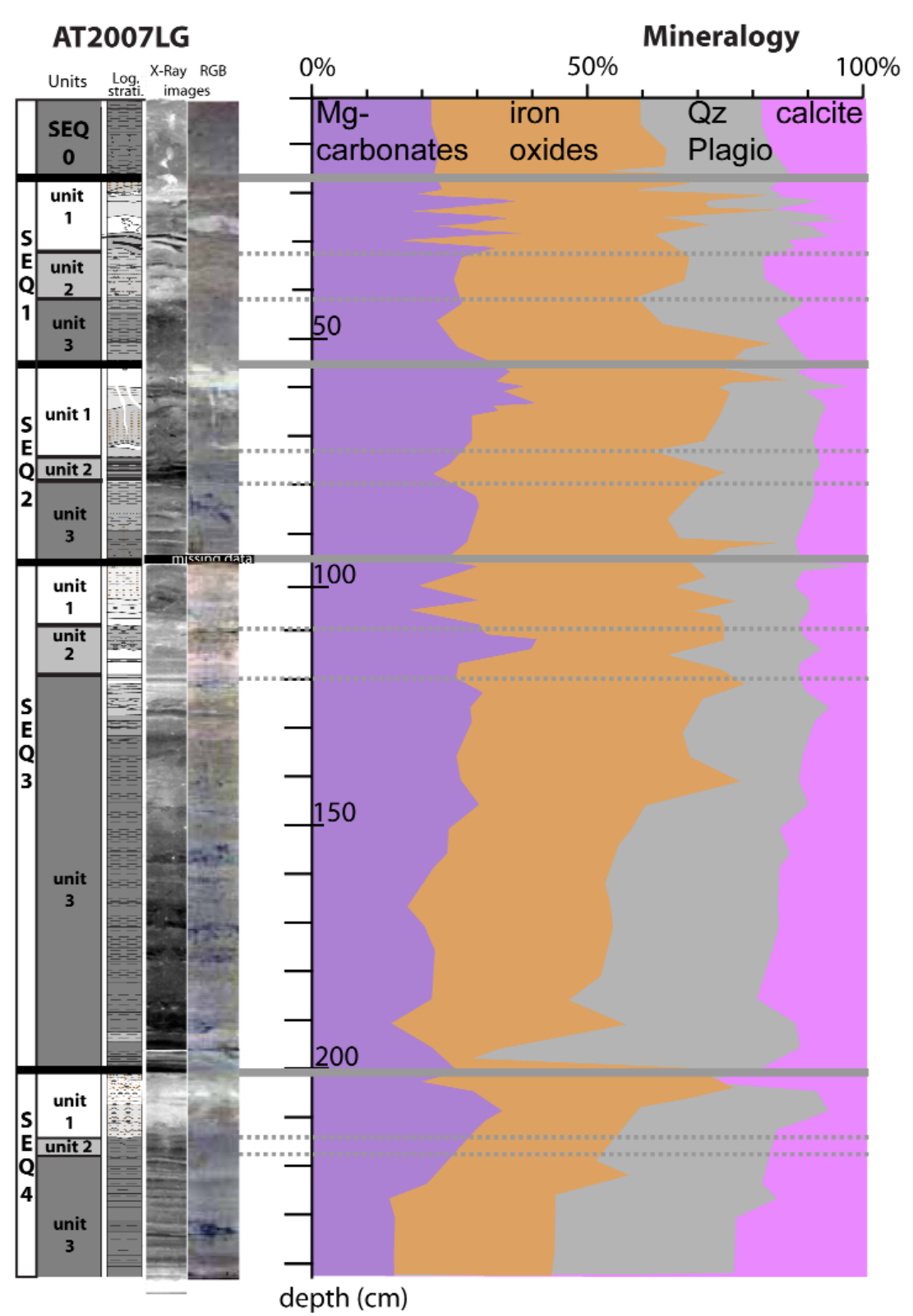

Figure 8. The 2.5-m-long AT2007LG core and mineralogical changes. From right to left: Division in three units of the four sequences of the core; detailed stratigraphic log; X-ray images; photographs of the core; XRD mineralogical changes with iron oxide, Mg-carbonate, quartz+plagioclase, calcite (quantification excluding clay minerals).

spectively). In some samples, aragonite was also detected.

The Aşağttepecik Lake mineralogy is unusual, with up to $40 \%$ iron oxides (hematite and goethite) and Ca-Mg carbonates (dolomite and hydromagnesite). In particular, hydromagnesite was identified. Hydromagnesite is a rare evaporitic hydrated magnesium carbonate $\left(\mathrm{Mg}_{5}\left(\mathrm{CO}_{3}\right)_{4}(\mathrm{OH})_{2} \cdot 4\left(\mathrm{H}_{2} \mathrm{O}\right)\right.$ ). Its occurrence implies that the lake was supersaturated with respect to $\mathrm{Mg}$, and had high total alkalinity, as $\mathrm{pH}>9$. To crystallize hydromagnesite directly from lake water, the $\mathrm{Mg}$ to-Ca ratio must be very high ( $>500)$ and the Mg concentration above $34 \mathrm{~g} / 1$ [Müller et al. 1972]. Hydromagnesite has been documented in a few lakes around the world. Those lakes are characterized by an arid climate [Van Der Borch 1965, Goto et al. 2003], by magnesium-rich ultramafic host rock [Power et al. 2007], or by a combination of both [Braithwaite and Zedef 1994]. In most lakes and wetlands around the world, the precipitation of hydromagnesite is catalyzed by cyanobacteria [Wright 1999, Braithwaite and Zedef 1996, Power et al. 2007]. In the presence of cyanobacteria, hydromagnesite can precipitate with a lower concentration and at a lower Mg:Ca ratio [Power et al. 2007].

For Aşağıtepecik Lake, the supersaturation in magnesium might have been reached through intense evaporation of its shallow water during the summer months. To reach the level required for precipitation of hydromagnesite, there must also be some significant $\mathrm{Mg}$ input from the catchment or from groundwater. The basement of the Golova Basin, an ophiolitique complex, is a natural source of magnesium. The iron oxides observed in Aşağıtepecik Lake core might also be derived from soil erosion around the lake. The alteration of the tertiary clastic carbonate infilling the basin is indeed producing iron-enriched topsoils. Cyanobacteria can also be im- 


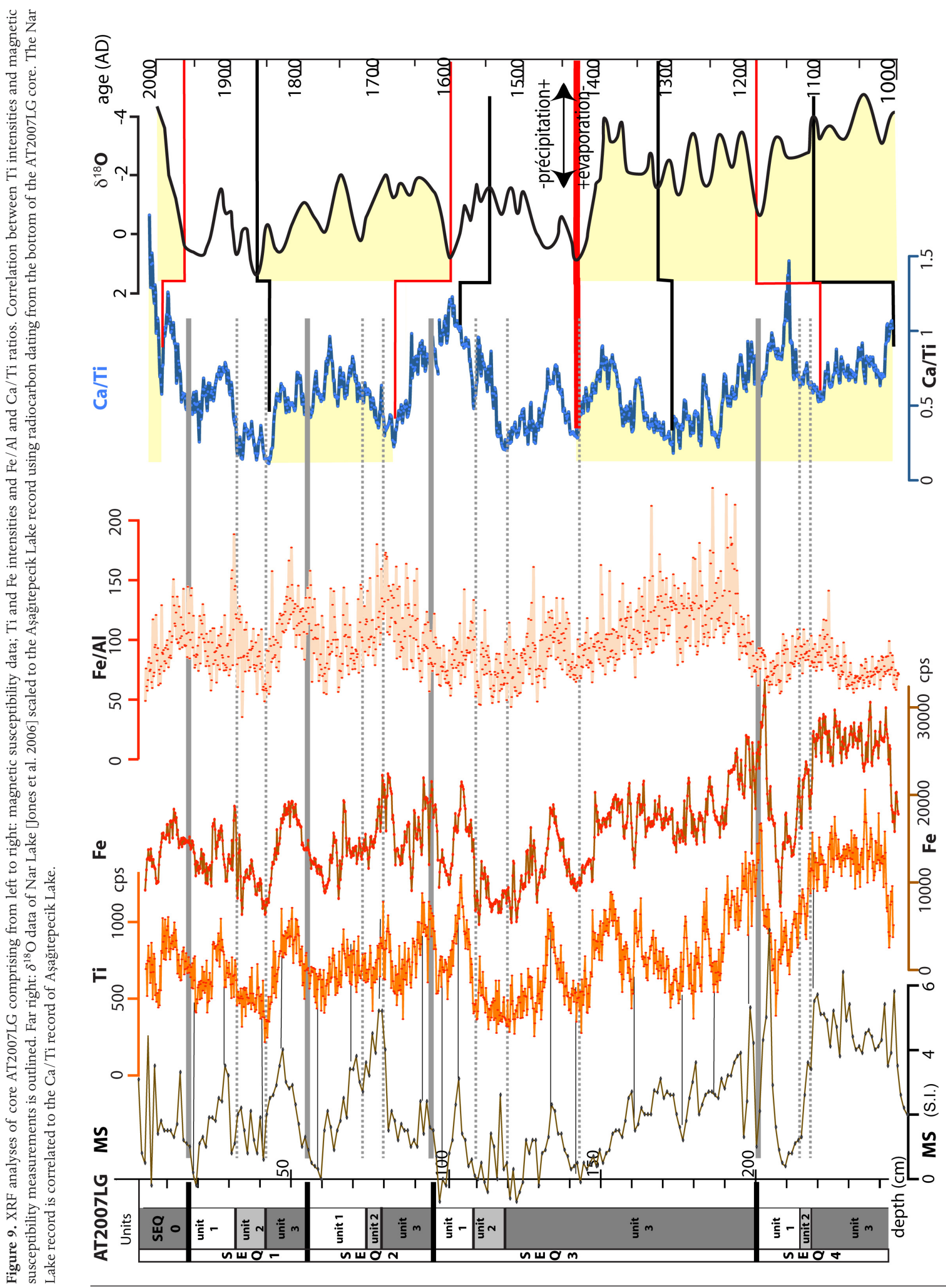


portant in the formation of iron-oxide in lake sediment.

In Figure 8, for AT2007, we present a cumulative diagram of the iron oxides (hematite+goethite), plagioglase plus quartz, Mg carbonates (dolomite+hydromagnesite) and calcite, excluding clays. The complete mineralogical data are presented in the Appendix. The detrital minerals (quartz and plagioclase) are presented together because they show similar evolution. They had high relative abundance from $250 \mathrm{~cm}$ to about $150 \mathrm{~cm}$, and at shallower depths, their proportions decreased. Local maxima and minima were reached in lamina in unit 1-seq.1. Iron oxides and $\mathrm{Mg}$ carbonates showed relatively low proportions in the $250 \mathrm{~cm}$ to $150 \mathrm{~cm}$ interval, and a higher proportion above $145 \mathrm{~cm}$. The maximum abundances in $\mathrm{Mg}$ carbonates were systematically reached in units 1 , with local minima in units 3 . The typical whitish color of unit 1 might be linked to a greater proportion of hydromagnetite, a white and light mineral. Calcite showed a trend similar to quartz plus plagioclase, and opposite to iron oxides plus $\mathrm{Mg}$ carbonates. The opposite trend of calcite and dolomite is expected, as high $\mathrm{Mg}$ calcite can react in water that has a $\mathrm{Mg} / \mathrm{Ca}$ ratio greater than seven, to form dolomite [Müller et al. 1972].

\subsubsection{X-ray fluorescence geochemical variations}

The titanium and iron intensities are presented in Figure 9. These elements are usually interpreted as representing the clastic terrigenous input. As strong variations in the organic matter content in the sediments can dilute counts in Ti and $\mathrm{Fe}$, we also present the $\mathrm{Fe} / \mathrm{Al}$ ratio. Aşağıtepecik Lake has a relatively simple hydrology, with no river inflows, so the iron allogenic input can be directly related to soil erosion along the shorelines, and thus to rainfall intensity.

$\mathrm{Ti}$ and Fe showed high-frequency variability. The comparison between $\mathrm{Ti}$ and $\mathrm{Fe}$ showed that part of the variation was noise. The correlation with the magnetic susceptibility data implied that small-scale variations still reflect compositional changes that are averaged out by mineralogical measurements that represent an average of the bulk composition over a $\mathrm{cm}$ or more. The Ti and Fe abundances, as well as the $\mathrm{Fe}-\mathrm{Al}$ ratio, showed relatively similar downcore variations, which suggested minor impact of organic matter variations on the XRF data. The Ti and Fe intensities decreased from the core bottom upwards, to reach minima at $145 \mathrm{~cm}$ and around $120 \mathrm{~cm}$. At shallower depths, the Ti intensity showed higher values with small-scale variations and another minima at $40 \mathrm{~cm}$ in depth. The Fe-Ti-XRF trends were also roughly similar to changes in detrital minerals, quartz-plagioclase (Figure 8). Coeval variations in Ti-Fe, detrital minerals, and magnetic susceptibility strengthen our interpretation that these proxies represent allogenic inputs to the lake (Figure 9).

Figure 9 also shows the Ca/Ti ratio, a proxy that is usually interpreted as representative of lake biogenic productivity with respect to terrigenous input [Drab et al. 2012]. The
$\mathrm{Ca} / \mathrm{Ti}$ ratio showed decreasing values from the core bottom, with minima in the $140 \mathrm{~cm}$ to $120 \mathrm{~cm}$ interval, at $85 \mathrm{~cm}$, and in the $45-\mathrm{cm}$ to $30-\mathrm{cm}$ interval. In addition, units 1 showed higher $\mathrm{Ca} / \mathrm{Ti}$ values with respect to units 2 and 3 in the same sequence, which is in agreement with the higher concentrations of ostracod shells found in these units (see next section).

5.2.5. Organic matter: loss-on-ignition analysis, total organic carbon, $\delta^{13} C$, and smear slides

The LOI data at $550{ }^{\circ} \mathrm{C}$ presented in Figure 10 show a mean organic content of $35 \%$, with strong variations between the different units. In particular, units 3 in sequences 2,3 and 4 had relative low organic content $(30 \%)$, whereas units 1 and 2 in all of the sequences showed relative maxima of up to $65 \%$ organic matter. We also observe a gradual upwards increase in organic matter from $25 \%$ at $208 \mathrm{~cm}$, to $35 \%$ at $145 \mathrm{~cm}$, which was linked to a visible increase in fiber density. Above these, there was a strong shift, with the organic matter reaching $60 \%$, and with lower values in the $95-\mathrm{cm}$ to 70-cm interval.

Smear slides of the different sieved fraction in units 1 to 3 helped in the characterization of the coarse $(>100 \mathrm{~m})$ material in the sediments, and particularly of the different types of organic material (Figure 7c). The content of the different units differed significantly, but all of these contained phytoclasts and silty-clay aggregates that formed soft grains of different sizes.

In units 3, the dominant fraction was usually greater than $450 \mu \mathrm{m}$ and was composed of elongated organic fibers, including Phragmites and Charophytes remains (Figure 7c). In units 1 , there was a greater diversity of materials and marked changes in organic content between the different lamina. An exception was seen for the strongly mixed unit 1-seq.4, which was relatively homogeneous (Figure 12). In unit 1-seq.1, the whitish top (see Figure 7a) showed high concentrations of seeds and Ephippia of Daphnia in the fraction $>450 \mu \mathrm{m}$. In the $450 \mu \mathrm{m}$ to $250 \mu \mathrm{m}$ fraction, about $60 \%$ was composed of seeds, most of which were black Charophyte seeds (gyrogonites). These high concentrations of black seeds were visible by eye in all of the units 1 (see Figures $6,8,12$ ). There were also high proportions of of ostracod shells (Figure $7 \mathrm{~b}$ ). In the $100 \mu \mathrm{m}$ to $250 \mu \mathrm{m}$ fraction, about $60 \%$ was composed of broken ostracod shells. Laminas below the whitish layer in unit 1-seq.1 (Figure $7 \mathrm{~b}$ ) had different contents. The fraction $>450$ $\mu \mathrm{m}$ was more abundant with large seeds, some chironomids, and different types of plant remains; the $250 \mu \mathrm{m}$ to $450 \mu \mathrm{m}$ fraction showed a mixture of broken ostracod shells in lower amounts than in the whitish layer, chironomids, seeds, phytoclasts, and amorphous silty-clay organic aggregates; the $100 \mu \mathrm{m}$ to $250 \mu \mathrm{m}$ fraction showed broken ostracoda in reduced abundance, and amorphous silty-clay organic aggregates. Units 2 had a highly variable content. Relative to units 1 , they showed less abundance of ostracods, and elongated fi- 


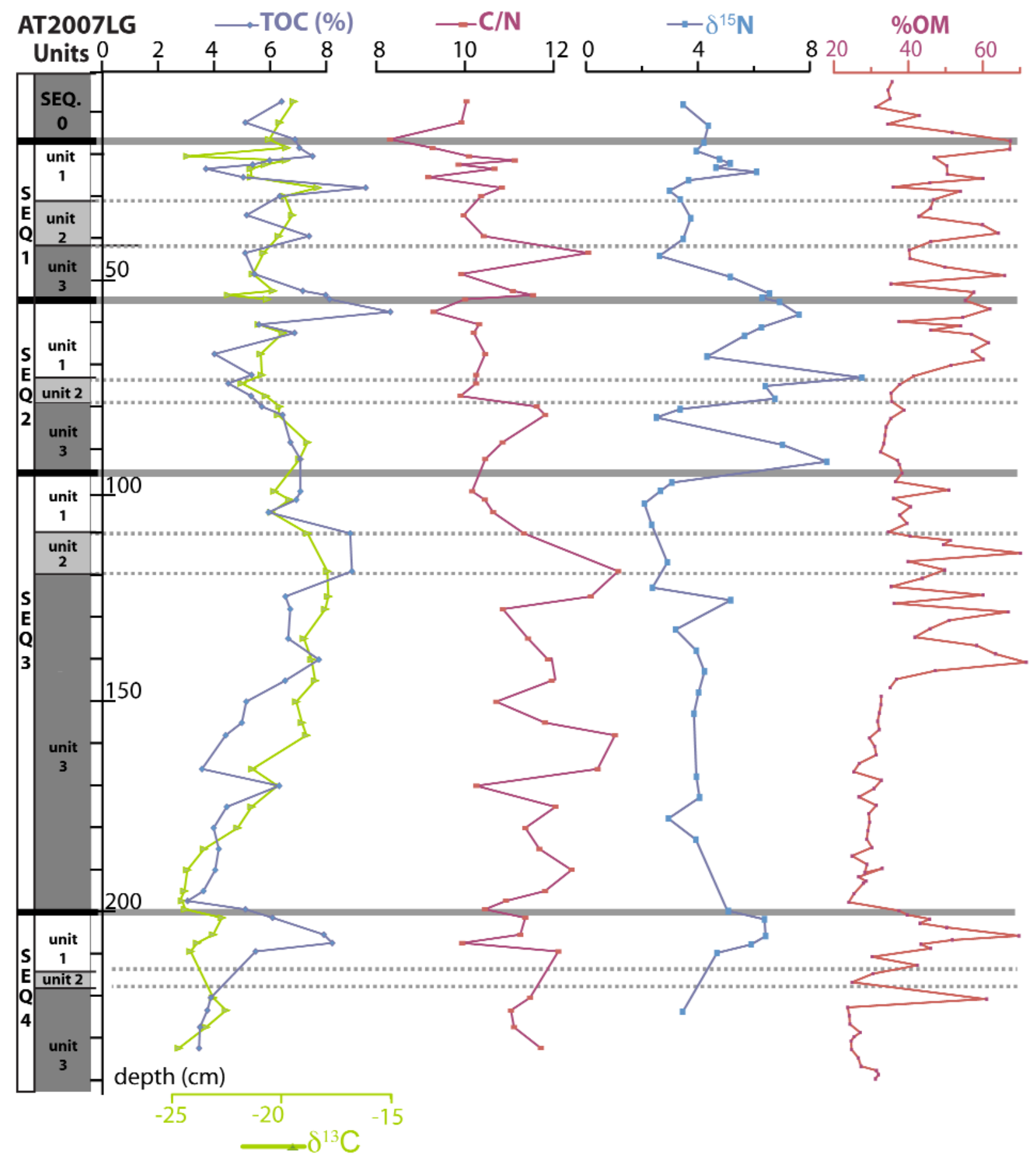

Figure 10. Analyses of the organic matter contained in the AT2007LG core combining LOI analysis $\left(550{ }^{\circ} \mathrm{C}\right), \delta^{13} \mathrm{C}, \mathrm{TOC}, \mathrm{C} / \mathrm{N}$ ratios and $\delta^{15} \mathrm{~N}$ measurements (from left to right).

brous plant remains, which were mostly absent in units 1 . The smear slides thus confirmed that units 2 were intermediate between units 1 and 3 .

The TOC data variations were similar to the $\mathrm{LOI}\left(550^{\circ} \mathrm{C}\right)$ data, although they were much smoother as the sampling interval is larger (Figure 10). The general trend of the TOC data was as follows. From the core bottom to the depth of $120 \mathrm{~cm}$, there was a general slow increase, with a local peak at $205 \mathrm{~cm}$ (unit 1-seq.4). This increase was followed by a general minor decrease to the depth of $70 \mathrm{~cm}$. At shallower levels, the TOC data showed high values and rapid variations.
Regarding the origin of the organic matter in Aşağıtepecik Lake, the C/ $\mathrm{N}$ ratio in AT2007LG oscillated around a mean of 11 , with a standard deviation of 1 (Figure 10). It was indeed dominated by the Phragmites and algae components. The ratio was slightly higher $(11.6 \pm 0.9)$ in the downwards part of the core, until $120 \mathrm{~cm}$ in depth, than in the upper part of the core $(10.4 \pm 0.8)$. The $\mathrm{C} / \mathrm{N}$ ratios were lower in units 1 , which were composed of a wider diversity of organic material.

The $\delta^{13} \mathrm{C}_{\text {org }}$ data followed trends similar to the TOC (Figure 10$)$. The low values $(-24.5 \%$ ) at the core bottom in- 
creased to a maximum $(-18 \%$ o) at a depth of about $120 \mathrm{~cm}$, then the $\delta^{13} \mathrm{C}_{\text {org }}$ data showed a decreasing trend to a minima $\left(-22 \%\right.$ ) at around $65 \mathrm{~cm}$. At shallower depths, the $\delta^{13} \mathrm{C}_{\text {org }}$ curve shows minor variations around the mean values of $-19 \%$ o to $-20 \%$ o. These changes in $\delta^{13} \mathrm{C}_{\text {org }}$ were probably not triggered by changes in productivity in the planktonic source, because there was no positive correlation with $\mathrm{Ca} / \mathrm{Ti}$ ratio, which is another proxy for lake productivity. The $\delta^{13} \mathrm{C}_{\mathrm{org}}$ most likely reflects changes in the source of the organic matter. Cyanobacteria have much higher $\delta^{13} \mathrm{C}_{\text {org }}$ values than algae or Phragmites. The rise in $\delta^{13} \mathrm{C}_{\text {org }}$ might thus be related to an increase in the cyanobacteria component in the lake.

The $\delta^{15} \mathrm{~N}$ data showed a trend opposite to $\delta^{13} \mathrm{C}_{\text {org }}$ (Figure 10). This negative correlation again points to changes in isotopic values that do not reflect changes in productivity [Haberzettl et al. 2005]. From the core bottom, the $\delta^{15} \mathrm{~N}$ values decreased, and reached their lowest values (2\%o) at depths between $120 \mathrm{~cm}$ and $100 \mathrm{~cm}$. Cyanobacteria have much lower $\delta^{15} \mathrm{~N}$ values than algae or Phragmites, so the observed changes in $\delta^{15} \mathrm{~N}$ values in the $100 \mathrm{~cm}$ to $250 \mathrm{~cm}$ interval might also represent an increase in the cyanobacteria component in the lake. In the $95 \mathrm{~cm}$ to $50 \mathrm{~cm}$ interval, the $\delta^{15} \mathrm{~N}$ reached high values of $10 \%$, which suggested that a major change occurred at that time [Hoefs 2009]. High $\delta^{15} \mathrm{~N}$ might indicate an input of allochthonous soil material into the lake [Haberzett et al. 2005]. At shallower depths, the $\delta^{15} \mathrm{~N}$ decreased again, sharply in the $45 \mathrm{~cm}$ to 28 $\mathrm{cm}$ interval, with minima around $2.6 \%$, corresponding to the minima in $\mathrm{Ti}$ (Figure 9).

\subsection{Dating}

The ${ }^{210} \mathrm{~Pb}-{ }^{137} \mathrm{Cs}$ data from the AT2006 core published in Boes et al. [2009] implied that unit 1-seq1 is related to the 1939 rupture, which occurred across the Aşağıtepecik Lake. All of the ${ }^{14} \mathrm{C}$ ages and sampled intervals are shown in Figure 11 and Table 1 . The ${ }^{14} \mathrm{C}$ ages of the bulk sediments ranged from $2580 \mathrm{BP}$ at $36 \mathrm{~cm}$ to $1850 \mathrm{BP}$ at $203 \mathrm{~cm}$, and they were not interpretable. Radiocarbon data showed that a strong reservoir effect occurred in Aşağıtepecik Lake, which might be linked to old dissolved inorganic carbon. Our results also signify that the reservoir effect in Aşağıtepecik Lake was not constant in time.

Radiocarbon dating on terrestrial seeds gave some reliable age constraints (Figure 11; Table 1). The $905 \pm 15 \mathrm{BP}{ }^{14} \mathrm{C}$ age of the terrestrial seeds at $211.5 \pm 5.5 \mathrm{~cm}$ was nearly identical to the $855 \pm 15 \mathrm{BP}{ }^{14} \mathrm{C}$ age at $231.5 \pm 3$.cm of the same type of seed. The calibrated ages imply that the 2.5 -m-long AT2007LG record spans about 900 yr. A rough sedimentation rate of $3 \mathrm{~mm} / \mathrm{yr}$ was thus inferred. The ${ }^{14} \mathrm{C}$ age of the terrestrial seeds in unit 1-seq. 3 was older than the seeds at greater depth. These seeds must have been reworked.

Samples of Ephippia of Daphnia at $238 \pm 10 \mathrm{~cm}(1030$ $\pm 15 \mathrm{BP})$ gave an age $175 \mathrm{yr}$ older than the terrestrial seeds at
$231.5 \pm 3 \mathrm{~cm}$ (Figure 11; Table 1). The observed offset suggested that the eggs had incorporating a proportion of old carbon from the lake. Furthermore, the ${ }^{14} \mathrm{C}$ ages of other Ephippia samples at $187.5 \pm 7.5 \mathrm{~cm}(1075 \pm 20 \mathrm{BP})$ and 157.5 $\pm 2.5 \mathrm{~cm}(1165 \pm 15 \mathrm{BP})$ were older, which suggests an upward-increasing reservoir effect that is consistent with the ${ }^{14} \mathrm{C}$ ages of the bulk sediments.

To refine our age model, we compared the Aşağıtepecik Lake record to that of the Nar Lake [Jones et al. 2006] in central Anatolia. The Nar $\delta^{18} \mathrm{O}$ data was considered as a proxy for the regional water balance, and this proxy is scaled in Figure 9 to show the last $1000 \mathrm{yr}$. It is compared to the $\mathrm{Ca} / \mathrm{Ti}$ ratio representing productivity changes in the Aşağıtepecik Lake (Figure 9). The Nar varved sediments recorded a strong aridification shift at AD 1400, which was linked to an increase in summer evaporation and a decrease in winter rainfall [Jones et al. 2006]. This aridification would correspond to the low Ca/Ti ratio at $145 \mathrm{~cm}$ in Aşağıtepecik Lake. We further argue in the next section that all of the proxies in the Aşağıtepecik Lake cores indicate a particularly low lake level at that depth. The two records can be further matched (Figures 9, 11 ); in particular the $\mathrm{Ca} / \mathrm{Ti}$ ratio and the $\delta^{18} \mathrm{O}$ show nearly identical variations at the top of the records. A more accurate age model of Aşağıtepecik Lake is thus obtained in Figure 11 by matching these two records. The refined sedimentation rate shows minor variations around a mean of $2.6 \mathrm{~mm} / \mathrm{yr}$.

\section{Interpretation}

\subsection{Recorded environmental changes}

The correlation between the Aşağıtepecik Lake and the Nar Lake records suggests that the sedimentological changes around the depths of $145 \mathrm{~cm}$ correspond to a regional $1400 \mathrm{AD}$ aridification [Jones et al. 2006] (Figure 9). Different proxies for Aşağıtepecik Lake confirm this interpretation (Figures 8, 9, 10).

From the depths of $145 \mathrm{~cm}$ to $95 \mathrm{~cm}$, the Aşağıtepecik Lake record shows: (1) high values for TOC, $\delta^{13} \mathrm{C}$, iron oxides and Mg carbonates; (2) low values for $\delta^{15} \mathrm{~N}$, plagioclase, quartz, calcite and Ti; and (3) a sudden increase in organic matter (LOI analysis) that reached $60 \%$ and was associated with very low magnetic susceptibility values (Figures 8, 9, 10). Low values for Ti and $\delta^{15} \mathrm{~N}$ point to reduced soil erosion, which is most likely caused by a decrease in precipitation. The coeval high values for iron oxide and in $\mathrm{Mg}$ carbonates, and low values for calcite imply a high $\mathrm{Mg} / \mathrm{Ca}$ ratio and high $\mathrm{Mg}$-Fe concentrations in the lake water. This points to a low lake level. The very high organic content also reflects very shallow water, and the shift to a location nearer to the vegetated near-shore environment. The isotopic values also reflect low water levels. Sifeddine et al. [2011] showed that in a shallow lake in Venezuela, the $\delta^{13} \mathrm{C}_{\text {org }}$ and TOC values increased, whereas the $\delta^{15} \mathrm{~N}$ values decreased along a transect from $4 \mathrm{~m}$ to $0 \mathrm{~m}$ in depth. Similarly 


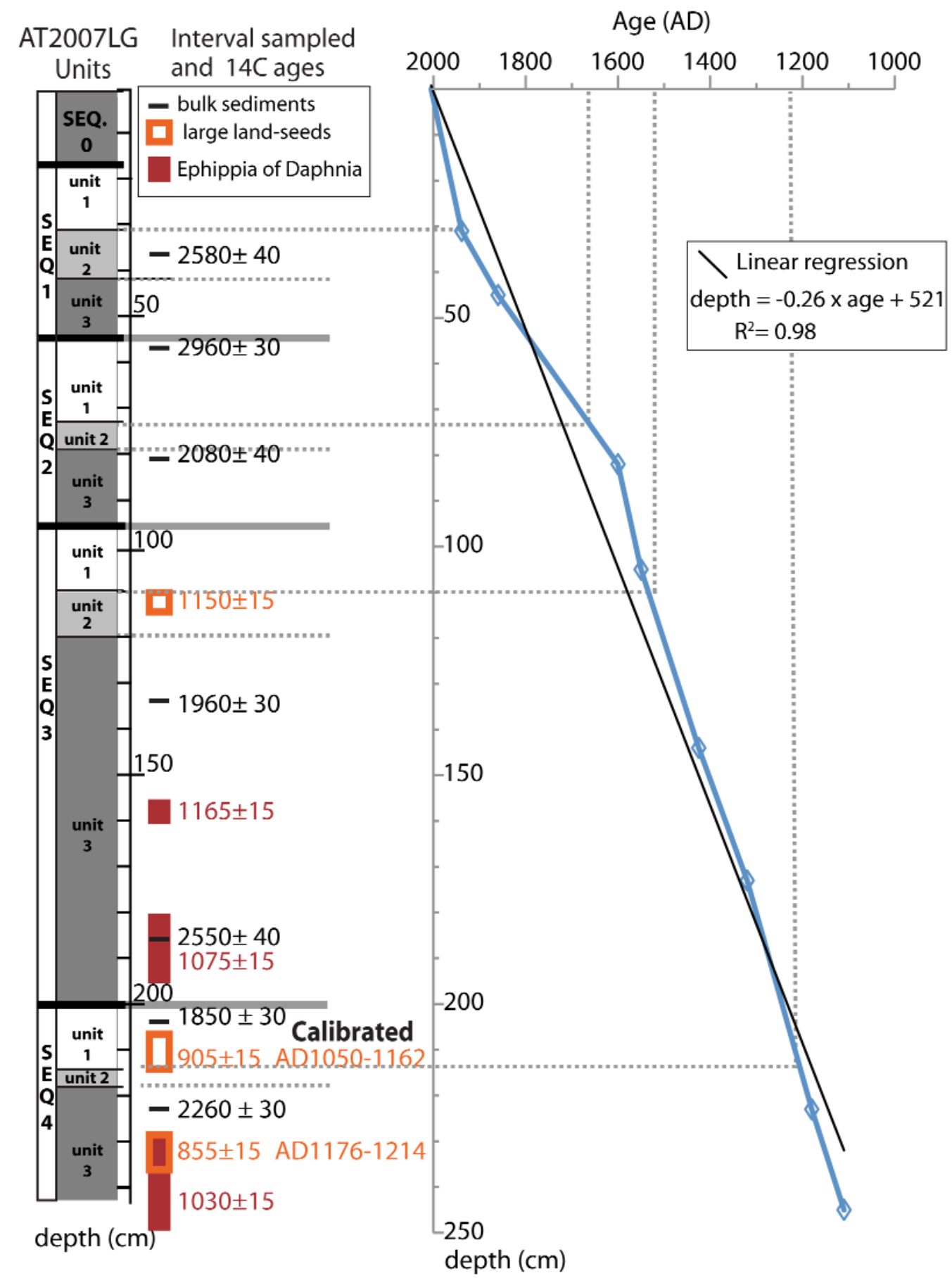

Figure 11. Age model of the AT2007 core based on the correlation in Figure 9. Left: stratigaphic division of core AT2007LG into sequences and units; right: intervals sampled for ${ }^{14} \mathrm{C}$ dating and obtained ages; far right: inferred sedimentation rates in Aşağıtepecik Lake. Ages for event horizons at the base of the units 1 can be inferred in this way.

Haberzettl et al. [2005] also indicated that $\delta^{13} \mathrm{C}_{\text {org }}$ values can be used as an indicator for water level, because higher $\delta^{13} \mathrm{C}_{\text {org }}$ values represent a higher macrophytic component. At low lake levels, the belt of submerged shoreline vegetation moves closer to the coring location, and the macrophytic component thus increases. The increase in $\delta^{13} \mathrm{C}_{\text {org }}$ and TOC from the core bottom to the depth of $145 \mathrm{~cm}$, and the decrease in $\delta^{15} \mathrm{~N}$, can thus be interpreted as reflecting a shallowing lacustrine environment. Another possible interpretation of the $\delta^{15} \mathrm{~N}-\delta^{13} \mathrm{C}_{\text {org }}$ data is linked to the possible presence of cyanobacteria catalyzing hydromagnesite.
Cyanobacteria have low $\delta^{15} \mathrm{~N}$ and high $\delta^{13} \mathrm{C}_{\text {org }}$ relative to the other organic components in the lake. A cyanobacteria bloom would decrease the $\delta^{15} \mathrm{~N}$ and increase the $\delta^{13} \mathrm{C}_{\text {org }}$. As the hydromagnesite and $\delta^{13} \mathrm{C}_{\text {org }}$ changes are coeval, this suggests that this interpretation is valid. Even if we cannot draw definitive conclusions regarding the interpretation of these stable isotope data, all other proxies point to a particularly low water level recorded in the Aşağıtepecik Lake sediments at $145 \mathrm{~cm}$ in depth. The shallow water level is probably associated with the regional 1400 AD aridity shift.

The Aşağıtepecik Lake record also shows some differ- 


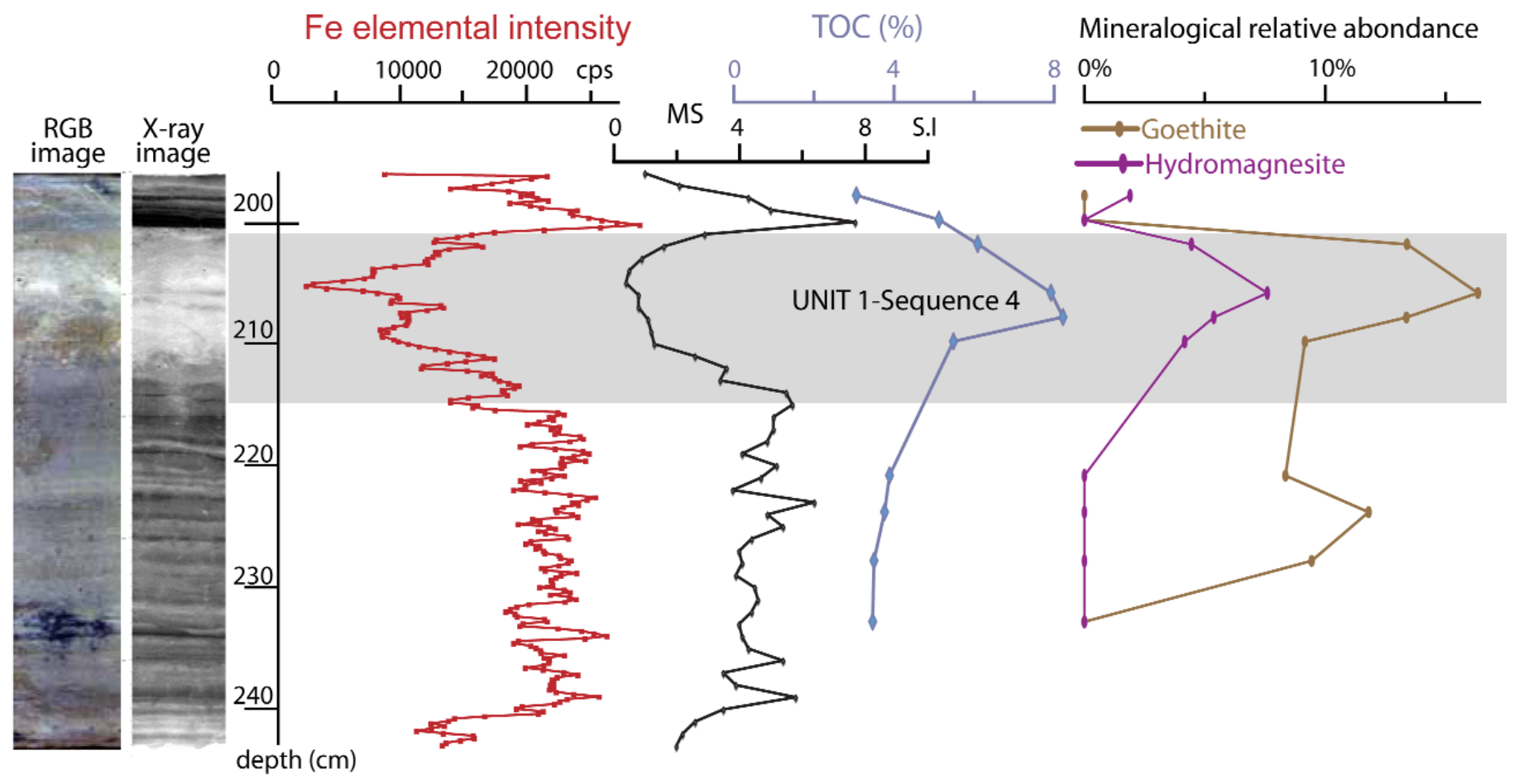

Figure 12. The bottom event in the core AT2007LG, and from left to right: RGB image and X-ray picture, Fe intensity, magnetic susceptibility, TOC, relative abundance of goethite and hydromagnesite in a quantification including quartz, plagioclase, clay, calcite, dolomite, hydromagnesite, hematite and goethite.

ences with that of the Nar Lake. First, the 1400 AD shift in aridity was not abrupt in the Aşağıtepecik Lake record. Gradual changes in geochemical, mineralogical and isotopic data occurred before the depth of $145 \mathrm{~cm}$ (Figures 8, 9, 10). These imply a slow decrease in water depth. Secondly, the very low water level is documented only in the $145 \mathrm{~cm}$ to $95 \mathrm{~cm}$ interval. At shallower depths, in the $90 \mathrm{~cm}$ to $70 \mathrm{~cm}$ interval, the lower $\delta^{13} \mathrm{C}_{\text {org }}$ values and organic matter percentages suggest that water deepening then occurred. This change is coeval with lower $\mathrm{C} / \mathrm{N}$ ratios and the very high $\delta^{15} \mathrm{~N}$ values. The slightly different $\mathrm{C} / \mathrm{N}$ values suggest a change in the balance of the origin of the organic matter in the lake. The very high $\delta^{15} \mathrm{~N}$ values point to a sudden and important soil input into the lacustrine system from an external source. This might be related to early anthropogenic modifications of the lake, such as the construction of a water channel between Aşağıtepecik Lake and Çobanlı River. Finally, the present values of $\delta^{13} \mathrm{C}_{\text {org }}$, $\mathrm{Ca} / \mathrm{Ti}, \mathrm{Mg}$ carbonates and iron oxides are higher than at the core bottom (e.g., $245 \mathrm{~cm}$ ), which suggest that the presentday lake level is still relatively low (Figures 8, 9, 10). This interpretation is compatible with the higher lake shores identified around Aşağıttepecik Lake (Figure 3, white arrows).

\subsection{Event stratigraphy}

The sediments in the long AT2007LG core, as well as those in the associated short cores, show disturbed sedimentary layers that are here called the units 1 (Figures 5, 8, $9,10,12)$. The radionuclide dating $(\mathrm{Pb}, \mathrm{Cs})$ implied that unit 1-seq. 1 is the seismite of the 1939 earthquake. The textural and structural characteristics of the unit agree with the cri- teria used by Matsuda [2000] to infer a seismic trigger in muddy sediments. During an earthquake, the water-sediment interface behaves like a mixed liquid, and part of the sediments is resuspended. The light and unbound elements are concentrated in a resuspension cloud and are then deposited according to their settlement velocities. The top part of unit 1 was indeed a homogenized layer with high concentrations of ostracods and seeds, mixed with phytoclasts. There was also an increase in the relative abundance of hydromagnesite, which has a low density (i.e., $2.25 \mathrm{~g} / \mathrm{cm}^{3}$ ). Matsuda [2000] also stated that earthquake shaking induces hydroplastic deformation in the lower parts of the uppermost unconsolidated layer. We observed flaser beds at the base of the unit, which suggests horizontal flow lines.

The other units 1 are also anomalous in terms of their structural organization, grain size, organic content, color and mineralogy. They might also represent earthquake-triggered sedimentary deposits. We compared them to unit 1seq. 1 to infer, or not, a seismic trigger. Unit 1-seq.4 is similar, with a whitish upper mixed layer and an upwardincreasing concentration of seeds and hydromagnesite (Figure 12). The bottom of unit 1-seq.4 shows dragged structures, which also suggest hydroplastic deformation [Matsuda 2000]. Unit 1-seq.2 has different sublayers that show a range of deformation patterns (Figure 5). The top whitish layer is characterized by a strong increase in hydromagnesite and can be interpreted as a resuspension deposit (Figure 8). The observed funnel-shaped intrusions lying below imply strong seismic shaking as recognized by Matsuda [2000]. The lower part of unit 1 has also been strained. In unit 1-seq.2, the de- 
formations in each internal sublayer appear synchronous. Indeed, seismic shaking in sediments with graded fluidity and plasticity will produced a range of deformations, which would be similar to what we observe [Matsuda 2000].

Unit 1-seq. 3 is not comparable to the others (Figures 5, 8 ) and it was deposited during the AD 1400-1600 aridification event. This unit in AT2007LG is structureless, but not in AT2006 (Figure 5). This mixing in AT2007LG might be related to other deformation mechanisms. We conclude that the seismic origin of the units 1 in the sequences 1,2 and 4 can be inferred without ambiguity, except for unit 1-seq.3.

\subsection{Event chronology}

The AT2007 core has four units 1 which might represent seismically disturbed sedimentary events. Event 1 (unit 1-seq.1) is related to the 1939 earthquake rupture that crossed Aşağıtepecik Lake. Radiocarbon dating indicates that event 4 (unit 1-seq.4) was deposited shortly after AD 1176-1214. The correlation with the Nar Lake record further suggests that event 2 occurred around AD 1650, event 3 around AD 1520 , and event 4 around AD 1230 (Figure 11).

This dating of the sedimentary events is compatible with the historical seismicity. The 1939 Erzincan earthquake triggered event 1 . Event 2 matches the $\mathrm{M}=81668$ earthquake [Ambraseys 2009]. Event 4 is compatible with the occurrence of the $\mathrm{M}=7.81254$ historical event [Ambraseys and Melville 1995]. Event 3 does not correspond to a large historical earthquake. Historical seismicity also includes an earthquake in 1543 [Ambraseys and Finkel 1995, Fraser et al. 2010], which might have ruptured the NAF or a nearby fault. This earthquake was reported in Çorum $(300 \mathrm{~km}$ WNW of Aşağıtepecik Lake), Erzincan (85 km ESE of Aşağıtepecik Lake) and Tokat (180 km WNW of Aşağıtepecik Lake). A strong event with an epicenter close to Aşağıtepecik Lake would leave traces on the sedimentation in the lake, even if it did not rupture the NAF segment that crosses the lake [e.g., Monecke et al. 2004].

\section{Discussion}

\subsection{Origin of the events identified}

The observed stratigraphy, with three distinctive units, is inferred to result from seismic shaking (Figures 5, 8, 9, 10, 12). Unit 3 is an undisturbed net of vertical organic fibers filled with silty-clay aggregates that are identical to the present background sedimentation. Unit 2 is similar to unit 3, but disturbed, with organic fibers forming laminas. Unit 2 would represent the lowermost sedimentary layer that was affected by some minor seismically induced plastic deformation. Unit 1 is anomalous and deformed. It has the highest organic content, with varied seeds, Ephippia of Daphnia, ostracod shells and phytoclasts. The stable isotope data further show a peak in $\delta^{15} \mathrm{~N}$ in units 1 in the sequence 1,2 and 4 , which could be linked to soil erosion. For the mineral fraction, the coeval goethite and hydromagnesite increase indicates reworking and soil erosion that concentrated $\mathrm{Fe}$ - and Mg-bearing elements in Aşağıtepecik Lake. A strong motion associated with a rupture across the lake would induce a large resuspension cloud and significant slope failures on the lake shores and of the fault scarp. In addition, strong seismic shaking would decrease cohesion and frictional strength of the top soils surrounding Aşağıtepecik Lake, which would increase the sediment delivery to the lake after the earthquake [Dadson et al. 2004]. We also need to point out that a $M>6$ earthquake in the Gölova Basin that ruptured one of the low-activity normal faults would also generate strong ground motion that would be capable of inducing resuspension, reworking and some slope failure along the shore. However, this earthquake shaking would be of lower amplitude than in the case of a rupture of the NAF segment crossing Aşağıtepecik Lake. The resulting deformation of the lacustrine sediment would thus be less important. This might be what triggered unit 1-seq. 3 .

Deformations observed in units 1 might have been triggered by other natural causes. Considering the present setting of Aşağıtepecik Lake, at least two main forcing agents can be identified: storms and droughts. Strong storms would have high wind speeds, which would induce sediment resuspension and increase sedimentary run-off in the lake. This process might account for some of the observed disturbances and anomalies. The lake is still located in a topographic low and is surrounded by vegetation, which provides some protection against strong winds. Furthermore, the average recurrence rate of units 1 in Aşağıtepecik Lake is about $300 \mathrm{yr}$, which is too long compare to the usual return period of strong storms. A significant drought would sharply decrease the lake level, concentrate the $\mathrm{Mg}$ and Fe elements in the lake water, and increase the precipitation of $\mathrm{Mg}$ carbonates and iron oxides, but this would not induce the strong mixing and disruptions observed in units 1 in sequences 1,2 and 4 . However, the very low water level prevailing at the time of unit 1seq. 3 might have increased the sensitivity of the topmost sediment to wave action during a very strong storm at the site of AT2007, but not at the site of AT2006.

In conclusion, the occurrence of units 1 in sequences 1 , 2 and 4 in Așağitepecik Lake fully matches historical earthquakes that ruptured the NAF strand crossing the lake. We thus believe that sedimentary events 1, 2 and 4 observed in Aşağıtepecik Lake were uniquely generated by earthquakes, which produced the variety of anomalies observed.

\subsection{Comparison with respect to other paleoseismological studies}

The inferred paleoearthquakes recorded for Aşağıtepecik Lake are the 1939, 1668, 1254 historical earthquakes. This record fully matches the paleoseismological data obtained from trenches located a few kilometers east of Aşağıtepecik Lake [Fraser et al., this volume]. Fraser et al. (this volume) 
did not document any earthquakes on the NAF between AD1400 and AD1600. Event 3, corresponding to unit 1-seq.3, might be related to a local $\mathrm{M}=6.5$ earthquake in the Gölova Basin, which would have ruptured one of the low activity normal faults that are bounding the basin.

\section{Conclusions}

Aşağıtepecik Lake occupies a small tectonic depression along the eastern NAF, and it has recorded regional climate changes and paleoearthquake occurrences. Geochemical, mineralogical and isotopic analyses of the AT2007LG core show the occurrence of a very low water depth at AD 1400, which corresponds to a regional aridification shift [Jones et al. 2006]. In addition, four disturbed sedimentary units disrupt the lacustrine organic-rich sedimentation. These units have anomalous mineralogical, organic, textural and structural characteristics. The anomalies are interpreted as resulting from resuspension, reworking of the sediments, and increases in sedimentary run-off into Aşağıtepecik Lake triggered by earthquake shaking. Four events were identified. Their ages were constrained by radiocarbon dating and correlation to a reference varved lacustrine record [Jones et al. 2006]. Event 1 corresponds to the 1939 earthquake. The associated rupture is still visible in seismic profiles across Aşağıtepecik Lake. Events 2 and 4 match the 1668 and 1254 historical events, respectively, which were also recorded in nearby paleoseismological trenches. Event 3 is not related to a paleoearthquake that ruptured the NAF segment crossing Aşağıtepecik Lake, but it might be related to a local earthquake on another fault in the Gölova Basin.

\section{Data and sharing sources}

The satellite images in Figures 2 and 3 are Google Earth imagery.

Acknowledgements. This work was carried out in the framework of the Marie Curie Excellence Grant Project Understanding the irregularity of seismic cycles: a case study in Turkey (MEXT-CT-2005-025617: Seismic Cycles), centered at the Seismology Section of the Royal Observatory of Belgium, whom we would like to thank for their support. We are grateful to Prof. Erhan Altunel and Sevgi Altinok for the assistance in logistics and field work. The seismic lines and the AT2007 cores were retrieved through a fruitful collaboration with EMCOL (Eastern Mediterranean Centre for Oceanography and Limnology) and its Director, Namık Çağatay. We would like to thank Emre Damci, who helped with the seismic acquisition and coring. We also acknowledge the work of Xavier Boes, who conducted the analysis of the AT2006 core published in Boes et al. [2009], actively participated in the coring mission in 2007, and acquired the magnetic susceptibility data on the AT2007LG core at Rhodes Island University. Finally, we thank an anonymous reviewer and Susan Leroy, who pointed out several weak points in our original manuscript.

\section{References}

Ambraseys, N.N. (1970). Some characteristic features of the North Anatolian Fault zone, Tectonophysics, 9, 143-165. Ambraseys, N.N., and C.F. Finkel (1988). The Anatolian earthquake of 17 August 1668, In: W.H.K. Lee, H. Meyers and K. Shimazaki (eds.), Historical Seismograms and Earthquakes of the World, Academic, San Diego, CA, 173-180.

Ambraseys, N.N., and C.F. Finkel (1995). The seismicity of Turkey and adjacent areas: a historical review, 1500-1800, Istanbul, Muhittin Salih Eren.

Ambraseys, N.N., and C.P. Melville (1995). Historical evidence of faulting in eastern Anatolia and northern Syria, Annali di Geofisica, 38 (3-4), 337-343.

Ambraseys, N.N., and J.A. Jackson (1998). Faulting associated with historical and recent earthquakes in the eastern Mediterranean region, Geophys. J. Int., 133, 390-406.

Ambraseys, N. (2009). Earthquakes in the Mediterranean and Middle East - A Multidisciplinary Study of Seismicity up to 1900, Cambridge University Press, 968 pp.

Barka, A.A., and K. Kadinsky-Cade (1988). Strike-slip fault geometry in Turkey and its influence on earthquake activity, Tectonics, 7, 663-684.

Barka, A.A. (1992). The North Anatolian Fault zone, Annales Tectonicæ, Special issue, Supplement to vol. 6, 164-195.

Barka, A.A. (1996). Slip distribution along the North Anatolian Fault associated with the large earthquakes of the period 1939 to 1967, Bull. Seismol. Soc. Am., 86, 1238-1254.

Beck, C., B. Mercier de Lepinay, J.-L. Schneider, M. Cremer, N. Cagatay, E. Wendenbaum, S. Boutareaud, G. Menot, S. Schmidt, O. Weber, K. Eris, R. Armijo, B. Meyer, N. Pondard, M.-A. Gutscher, and the MARMACORE Cruise Party, J.-L. Turon, L. Labeyrie, E. Cortijo, Y. Gallet, H. Bouquerel, N. Gorur, A. Gervais, M.-H. Castera, L. Londeix, A. de Resseguier and A. Jaouen (2007). Late Quaternary co-seismic sedimentation in the Sea of Marmara's deep basins, In: F. Bourrouilh-Le Jan, C. Beck and D. Gorsline (eds.), Sedimentary Records of Catastrophic Events, Sedimen. Geol., 199, 65-89.

Beck, C. (2009). Late Quaternary lacustrine paleo-seismic archives in north-western Alps: examples of earthquakeorigin assessment of sedimentary disturbances, Earth Sci. Rev., 96, 327-344.

Becker, A., M. Ferry, M. Schnellmann and D. Giardini (2005). Multiarchive palæoseismic record of late Pleistocene strong earthquakes in Switzerland, Tectonophysics, 400, 153-157.

Bertrand, S., F. Charlet, E. Chapron, N. Fagel and M. De Batist (2007). Reconstruction of the Holocene seismotectonic activity of the southern Andes from seismites recorded in Lago Icalma, Chile, $39^{\circ} \mathrm{S}$, Palaeogeogr. Palaeoclimatol. Palaeoecol., 259, 301-322.

Bertrand, S., M. Sterken, L. Vargas-Ramirez, M. De Batist, W. Vyverman, G. Lepoint and N. Fagel (2009). Bulk organic geochemistry of sediments from Puyehue Lake and its watershed (Chile, $40^{\circ} \mathrm{S}$ ): implications for paleoenvironmental reconstructions, Palaeogeogr. Palaeoclimatol. 
Palaeoecol., 294, 56-71; doi:10.1016/j.palaeo.2009.03.012. Bertrand, S., L. Doner, S. Akcer On, U. Sancar, U. Schudack, S. Mischke, N. Cagatay and S.A.G. Leroy (2011). Sedimentary record of coseismic subsidence in Hersek coastal lagoon (Izmit Bay, Turkey) and the late Holocene activity of the North Anatolian Fault, Geochem. Geophys. Geosyst., 12, Q06002; doi:10.1029/2011GC003511.

Boes, X., S.B. Moran, J. King, M.N. Cagatay and A. HubertFerrari (2009). Records of large earthquakes in lake sediments along the North Anatolian Fault, Turkey, J. Paleolimnol., 43, 901-920; doi:10.1007/s10933-009-9376-x. Braithwaite, C., and V. Zedef (1994). Living hydromagnesite stromatolites from Turkey, Sediment. Geol., 92; doi:10.1016/0037-0738(94)90051-5.

Braithwaite, C., and V. Zedef (1996). Hydromagnesite sStromatolites and sediments in an alkaline lake, Salda Golu, Turkey, J. Sediment. Res., 66; doi:10.1306/D426845F2B26-11D7-8648000102C1865D.

Carrillo, E., C. Beck, F. Audemard, E. Moreno and R. Ollarves (2008). Disentangling Late Quaternary climatic and seismo-tectonic controls on Lake Mucubaji sedimentation (Merida Andes, Venezuela), Palaeogeogr. Palaeoclimatol. Palaeoecol., 259, 284-300.

Chapron, E., C. Beck, M. Pourchet and J-F. Deconinck (1999). 1822 earthquake-triggered homogenite in Lake Le Bourget (NW Alps), Terra Nova, 11, 86-92.

Cochran, U., M. Hannah, M. Harper, R. Van Dissen, K. Berryman and J. Begg (2007). Detection of large, Holocene earthquakes using diatom analysis of coastal sedimentary sequences, Wellington, New Zealand, Quat. Sci. Rev., 26, 1129-1147, ISSN 0277-3791; doi:10.1016/j. quascirev.2007.01.008.

Croudace, I.W., A. Rindby and R.G. Rothwell (2006). ITRAX: description and evaluation of a new multi-function X-ray core scanner, In: R.G. Rothwell (ed.), New Techniques in Sediment Core Analysis, Special publication 267, Geological Society, London, 51-63.

Dadson, S.J., N. Hovius, H. Chen, W.B. Dade, J.-C. Lin, M.L. Hsu, C.-W. Lin, M.-J. Horng, T.-C. Chen, J. Milliman and C.P. Stark (2004). Earthquake-triggered increase in sediment delivery from an active mountain belt, Geology, 32, 733-736.

Drab, L., A. Hubert Ferrari, S. Schmidt and P. Martinez, P (2012). The earthquake sedimentary record in the western part of the Sea of Marmara, Turkey, Nat. Hazards Earth Syst. Sci., 12, 1235-1254; doi:10.5194/nhess-12-12352012.

Farnsworth, E.J., and L.A. Meyerson (2003). Comparative ecophysiology of four wetland plant species along a continuuum of invasiveness, Wetlands, 23, 750-762.

Fogel, M.L., and L.A. Cifuentes (1993). Isotope fractionation during primary production, In: M.H. Engel and S.A. Macko (eds.), Organic geochemistry principles and ap- plications, Plenum, New York, 73-94.

Fraser, J., K. Vanneste and A. Hubert-Ferrari (2010). Recent behavior of the North Anatolian Fault: insights from an integrated paleoseismological dataset, J. Geophys. Res., 115; doi:10.1029/2009JB006982.

Garcia Moreno, D., A. Hubert-Ferrari, J. Moernaut, J. Fraser, X. Boes, M. Van Daele, M. De Batist, E. Damci and N. Cagatay (2010). Structure and evolution of Lake Hazar pullapart Basin along the East Anatolian Fault, Basin Res., 23, 191-207.

Goldfinger, C., C.H. Nelson and J.E. Johnson (2003). Holocene earthquake records from the cascadia subduction zone and northern San Andreas Fault based on precise dating of offshore turbidites, Ann. Rev. Earth Planet. Sci., 31, 555-577.

Goldfinger, C., A. Morey and H. Nelson (2006). Deep-water turbidites as Holocene earthquake proxies along the northern San Andreas Fault system, Seismol. Res. Lett., 77, 195-196.

Goldfinger, C., A. Morey, C. Nelson, J. Gutierrez-Pastor, J. Johnson, E. Karabanov, J. Chaytor and A. Eriksson (2007). Shipboard scientific party, rupture lengths and temporal history of significant earthquakes on the offshore and north coast segments of the northern San Andreas Fault based on turbidite stratigraphy, Earth Planet. Sci. Lett., 254, 9-27.

Gorsline, D.S., T. De Diego and E.H. Nava-Sanchez (2000). Seismically triggered turbidites in small margin basins: Alfonso Basin, western Gulf of California and Santa Monica Basin, California Borderland, Sediment. Geol., 135, 21-35.

Goto, A., H. Arakawaa, H. Morinagaa and T. Sakiyamab (2003). The occurrence of hydromagnesite in bottom sediments from Lake Siling, central Tibet: implications for the correlation among $\delta^{18} \mathrm{O}, \delta^{13} \mathrm{C}$ and particle density, J. Asian Earth Sci., 21, 979-988.

Guidoboni, E., A. Comastri and G. Traina (1994). Catalogue of Ancient Earthquakes in the Mediterranean Area up to the 10th Century, INGV-SGA, Bologna.

Haberzettl, T., M. Fey, Andreas, A. Lücke, N. Maidana, C. Mayr, C. Ohlendorf, F. Schäbitz, G.H. Schleser, M. Wille and B. Zolitschka (2005). Climatically induced lake-level changes during the last two millennia as reflected in sediments of Laguna Potrok Aike, southern Patagonia (Santa Cruz, Argentina), J. Paleolimnol., 33, 283-302.

Hartleb, R., D. Dolan, J.F. Kozac1, H.S. Akyuz and G.G. Seitz (2006). A 2500-yr-long paleoseismologic record of large, infrequent earthquakes on the North Anatolian Fault at Cukurcimen, Turkey, Bull. Geol. Soc. Am., 118, 823-840; doi:810.1130/B25838.25831.

Hayward, B., H. Grenfell, A. Sabaa, R. Carter, U. Cochran, J. Lipps, P. Shane and M. Morley (2005). Micropaleontological evidence of large earthquakes in the past 7200 years in southern Hawke's Bay, New Zealand, Quat. Sci. Rev., 25, 1186-1207, ISSN 0277-3791; doi: 10.1016/ j.quas 
cirev.2005.10.013.

Hoefs, J. (2009). Stable Isotope Geochemistry, Springer, 197 pp. Hubert-Ferrari, A., A. Barka, E. Jacques, S. Nalbant, B. Meyer, R. Armijo, P. Tapponnier and G.C.P. King (2000). Seismic hazard in the Sea of Marmata following the Izmit earthquake, Nature, 404, 269-273.

Hubert-Ferrari, A., R. Armijo, B. Meyer, G.C.P. King and A. Barka (2002). Morphology, displacement and slip rates along the North Antolian Fault (Turkey), J. Geophys. Res., 107; doi:10.1029/2001JB000393.

Hubert-Ferrari, A., X. Boes, J. Fraser, U. Avsar, K. Vanneste, N. Cagatay, E. Altunel, M. de Batist and N. Fagel (2007). Understanding the irregularity of seismic cycles: A Case study in Turkey - A Marie Curie Excellence Team Project, European Geosciences Union Meeting, Geophysical Research Abstract, 9, 06720, Poster.

Jones, M., N. Roberts, M.J. Leng and M. Turkes (2006). A high-resolution late Holocene lake isotope record fromTurkey and links to North Atlantic and monsoon climate, Geology, 34, 361-364; doi:10.1130/G22407.1.

Klinger, Y., K. Sieh, E. Altunel, A. Akoglu, A. Barka, T. Dawson, T. Gonzales, A. Meltzner and T. Rockwell (2003). Paleoseismic evidence of characteristic slip on the western segment of the North Anatolian Fault, Turkey, Bull. Seis. Soc. Am., 93, 2317-2332.

Koçyiğit, A. (1990). Tectonic setting of the Gölova basin, total offset of the North Anatolian Fault zone, eastern Pontide, Turkey, Annales Tectonicæ, 4, 155-170.

Kozac1, O., J.F. Dolan, R.C. Finkel and R.D. Hartleb (2007). Late Holocene slip rate for the North Anatolian Fault, Turkey, from cosmogenic ${ }^{36} \mathrm{Cl}$ geochronology: implications for the constancy of fault loading and strain release rates, Geology, 35, 867-870; doi:10.1130/ G23187A.1.

Kozac1, O., J. Dolan, O. Yönlü and R. Hartleb (2011). Paleoseismologic evidence for the relatively regular recurrence of infrequent, large-magnitude earthquakes on the eastern North Anatolian Fault at Yaylabeli, Turkey, Lithosphere, 3, 37-54; doi:10.1130/L118.1.

Larrasoana, J., M. Ortuno, H. Birks, B. Valero-Garces, J. Pares, R. Copons, L. Camarero and J. Bordonau (2010). Palaeoenvironmental and palaeoseismic implications of a 3700-year sedimentary record from proglacial Lake Barrancs (Maladeta Massif, central Pyrenees, Spain), Palaeogeogr. Palaeoclimatol. Palaeoecol., 294, 83-93, ISSN 0031-0182; doi:10.1016/j.palaeo.2009.04.003.

Leroy, S., N. Kazanci, O. Ileri, M. Kibar, O. Emre, E. McGee and H.I. Griffiths (2002). Abrupt environmental changes within a late Holocene lacustrine sequence south of the Marmara Sea (Lake Manyas, N-W Turkey): possible links with seismic events, Marine Geol., 190, 531-552, ISSN 0025-3227; doi:10.1016/S0025-3227(02)00361-4.

Leroy, S., S. Boyraz and A. Gurbuz (2009). High-resolution palynological analysis in Lake Sapanca as a tool to detect recent earthquakes on the North Anatolian Fault, Quat. Sci. Rev., 28, 2616-2632, ISSN 0277-3791; doi: 10.1016/j. quascirev.2009.05.018.

Leon, L.A., J.F. Dolan, J.H. Shaw and T.L. Pratt (2009). Evidence for large Holocene earthquakes on the Compton thrust fault, Los Angeles, California, J. Geophys. Res., 114, B12305; doi:10.1029/2008JB006129.

Liu, J., Y. Klinger, X. Xu, C. Lasserre, G. Chen, W. Chen and P. Tapponnier (2007). Millenial recurrence of large earthquakes on the Haiyuan fault near Songshan, Gansu province, China, Bull. Seis. Soc. Am., 97, 14-34.

Lowemark, L., H.-F. Chen, T.-N. Yang, M. Kylander, E.-F. Yu, Y.-W. Hsu, T.-Q. Lee, S.-R. Song and S. Jarvis (2011). Normalizing XRF-scanner data: a cautionary note on the interpretation of high-resolution records from organic-rich lakes, J. Asian Earth Sci., 40, 1250-1256.

Marco, S., and A. Agnon (2005). High-resolution stratigraphy reveals repeated earthquake faulting in the Masada Fault zone, Dead Sea transform, Tectonophysics, 408, 101-112.

Matsuda, J.-I. (2000). Seismic deformation structures of the post-2300 a BP muddy sediments in Kawachi lowland plain, Osaka, Japan, Sediment. Geol., 135, 99-116.

McCalpin, J. (2009). Paleoseismology, Academic Press, Nature, $613 \mathrm{pp}$.

Meyers, P.A., and J.L. Teranes (2001). Sediment organic matter, In: W.M. Last and J.P. Smol (eds.), Tracking Environmental Changes Using Lake Sediment. Physical and geochemical methods, Kluwer Academic, Dordrecht, The Netherlands, 2, 239-270.

Migeon, S., O. Weber, J. Faugeres and J. Saint-Paul (1999). SCOPIX: a new X-ray imaging system for core analysis, Geo-Marine Lett., 18, 251-255.

Moernaut, J., M. De Batist, F. Charlet, K. Heirman, E. Chapron, M. Pino, R. Brummer and R. Urrutia (2007). Giant earthquakes in south-central Chile revealed by Holocene mass-wasting events in Lake Puyehue, Sediment. Geol., 195, 239-256.

Moernaut, J., M. De Batist, K. Heirman, M. Van Daele, M. Pino, R. Brummer and R. Urrutia (2009). Fluidization of buried mass-wasting deposits in lake sediments and its relevance for paleoseismology: results from a reaction seismic study of lakes Villarrica and Calafquen (south-central Chile), Sediment. Geol., 213, 121-135.

Monecke, K., F.S. Anselmetti, A. Becker, M. Sturm and D. Giardini (2004). The record of historic earthquakes in lake sediments of central Switzerland, Tectonophysics, 394, 21-40.

Müller, G., G. Irion and U. Forstner (1972). Formation and diagenesis of inorganic $\mathrm{Ca}-\mathrm{Mg}$ carbonates in the lacustrine environment, Natürwissenschaften, 59, 158-164.

Nakajima,T., and Y. Kanai (2000). Sedimentary features of seismoturbidites triggered by the 1983 and older histori- 
cal earthquakes in the eastern margin of the Japan Sea, Sediment. Geol., 135, 1-19; doi:10.1016/S0037-0738(00) 00059-2.

Okomura, K., T. Yoshioka and I. Kusçu (1994). Surface faulting on the North Anatolian Fault in these two millennia, Proceedings of the Workshop on Paleoseismology, OpenFile Report 94-568, USGS, 143-144.

Power, I., S. Wilson, J. Thom, G. Dipple and G. Southam (2007). Biologically induced mineralization of dypingite by cyanobacteria from an alkaline wetland near Atlin, British Columbia, Canada, Geochem.1 Trans., 8, doi:10. 1186/1467-4866-8-13.

Reilinger, R., S. McClusky, P. Vernant, S. Lawrence, S. Ergintav, R. Cakmak, H. Ozener, F. Kadirov, I. Guliev, R. Stepanyan, M. Nadariya, G. Hahubia, S. Mahmoud, K. Sakr, A. ArRajehi, D. Paradissis, A. Al-Aydrus, M. Prilepin, T. Guseva, E. Evren, A. Dmitrotsa, S.V. Filikov, F. Gomez, R. Al-Ghazzi and G. Karam (2006). GPS constraints on continental deformation in the Africa-Arabia-Eurasia continental collision zone and implications for the dynamics of plate interactions, J. Geophys. Res., 111, B05411; doi:10.1029/2005JB004051.

Richter, T.O., S. Van der Gaast, B. Koster, A. Vaars, R. Gieles, H. De Stigter, H. De Haas and T.C.E. van Weering (2006). The Avaatech XRF core scanner: technical description and applications to NE Atlantic sediments, In: R.G. Rothwell (ed.), New Techniques in Sediment Core Analysis, Special Publication 267, Geological Society, London, 39-50.

Rothwell, R.G., and F.R. Rack (2006). New techniques in sediment core analysis: an introduction, In: R.G. Rothwell (ed.), New Techniques in Sediment Core Analysis, Special Publication 267, Geological Society, London, 1-29.

Shiki, T., F. Kumon, Y. Inouchi, Y. Kontani, T. Sakamotoe, M. Tateishi, H. Matsubara and K. Fukuyama (2000). Sedimentary features of the seismo-turbidites, Lake Biwa, Japan, Sediment. Geol., 135, 37-50.

Schnellmann, M., F.S. Anselmetti, D. Giardini, J.A. McKenzie and S. Ward (2002). Prehistoric earthquake history revealed by lacustrine slump deposits, Geology, 30, 1131-1134.

Schwab, M., P. Werner, P. Dulski, E. McGee, N. Nowaczyk, S. Bertrand and S. Leroy (2009). Palaeolimnology of Lake Sapanca and identification of historic earthquake signals, Northern Anatolian Fault zone (Turkey), Quat. Sci. Rev., 28, 991-1005.

Sifeddine, A., P.M. Meyers, R.C. Cordeiro, A. Luiza, S. Albuquerque, M. Bernardes, B. Turcq and J.J. Abrao (2011). Delivery and deposition of organic matter in surface sediments of Lagoa do Cacço (Brazil), J. Paleolimnol, 45, 385-396; doi:10.1007/s10933-011-9506-0.

Stein, R.S., A.A. Barka and J.H. Dieterich (1997). Progressive failure on the North Anatolian Fault since earthquake stress triggering, Geophys. J. Int., 128, 594-604.
Sterner, R.W., and J.J. Elser (2002). Ecological Stoichiometry: the Biology of Elements from Molecules to the Biosphere, Princeton University Press, Princeton.

Talbot, M.R., and T. Lærdal (2000). The Late Pleistocene Holocene palaeolimnology of Lake Victoria, east Africa, based upon elemental and isotopic analyses of sedimentary organic matter, J. Paleolimnol., 23, 141-164.

Van Der Borch, C. (1965). The distribution and preliminary geochemistry of modern carbonate sediments of the Coorong area, south Australia, Geochim. Cosmochim. Acta, 29, 781-799.

Wainright, S.C., M.P.Weinstein, K.W. Able and C.A. Currin (2000). Relative importance of benthic microalgae, phytoplankton and the detritus of smooth cordgrass Spartina alterniflora and the common reed Phragmites australis to brackish marshfood webs, Mar. Ecol. Prog. Ser., 200, 77-91.

Weldon, R.J., K.M. Scharer, T.E. Fumal and G.P. Biasi (2004). Wrightwood and the earthquake cycle: what a long recurrence record tells us about how faults work, GSA Today, 14, 4-10.

Weltje, G.J., and R. Tjallingii (2008). Calibration of XRF core scanners for quantitative geochemical logging of sediment cores: theory and application, Earth Planet. Sci. Lett., 274, 423-438.

Wright, D. (1999). The role of sulphate-reducing bacteria and cyanobacteria in dolomite formation in distal ephemeral lakes of the Coorong region, south Australia, Sediment. Geol., 126, 147-157; doi:10.1016/S0037-0738(99)00037-8.

Zabci, C., V. Karabacak, T. Sancar, H.S. Akyuz, E. Altunel, H. Gursoy and O. Tatar (2008). The possible eastward continuation of the 17 August 1668 Anatolian Earthquake on the North Anatolian Fault (NAF), Turkey, Geophys. Res. Abstracts 10, EGU2008-A-05542.

Zabci, C., H.S. Akyuz, V. Karabacak, T. Sancar, E. Altunel, H. Gursoy and O. Tatar (2011). Paleoearthquakes on the Kelkit Valley segment of the North Anatolian Fault, Turkey: implications for the surface rupture of the historical 17 August 1668 Anatolian Earthquake, Turkish J. Earth Sci., 20, 411-427.

\footnotetext{
${ }^{\star}$ Corresponding author: Aurelia Hubert-Ferrari, University of Liege, Department of Geography, Unit of Physical and Quaternary Geography, Liège, Belgium; email: aurelia.ferrari@ulg.ac.be.
}

(C) 2012 by the Istituto Nazionale di Geofisica e Vulcanologia. All rights reserved. 


\section{Appendix}

X-ray diffraction mineralogy of core AT2007LG.

\begin{tabular}{|c|c|c|c|c|c|c|c|c|}
\hline $\begin{array}{l}\text { Depth } \\
(\mathrm{cm})\end{array}$ & $\begin{array}{l}\text { Quartz } \\
(\%)\end{array}$ & $\begin{array}{c}\text { Calcite } \\
(\%)\end{array}$ & $\begin{array}{l}\text { Dolomite } \\
(\%)\end{array}$ & $\begin{array}{l}\text { Clay } \\
(\%)\end{array}$ & $\begin{array}{l}\text { Plagioclase } \\
\text { (\%) }\end{array}$ & $\begin{array}{c}\text { Hematite } \\
(\%)\end{array}$ & $\begin{array}{c}\text { Goethite } \\
(\%)\end{array}$ & $\begin{array}{c}\text { Hydro-magnesite } \\
(\%)\end{array}$ \\
\hline 14.5 & 7 & 10 & 7 & 50 & 5 & 5 & 13 & 4 \\
\hline 19.5 & 6 & 8 & 7 & 48 & 6 & 6 & 15 & 4 \\
\hline 23 & 4 & 9 & 6 & 54 & 5 & 6 & 12 & 5 \\
\hline 24 & 3 & 9 & 5 & 48 & 13 & 4 & 13 & 4 \\
\hline 24.5 & 4 & 10 & 8 & 46 & 6 & 4 & 17 & 5 \\
\hline 25 & 4 & 7 & 10 & 44 & 0 & 5 & 22 & 8 \\
\hline 25.5 & 4 & 5 & 10 & 51 & 5 & 5 & 13 & 7 \\
\hline 27 & 4 & 9 & 6 & 51 & 4 & 4 & 16 & 4 \\
\hline 27.5 & 6 & 8 & 5 & 49 & 7 & 7 & 14 & 4 \\
\hline 28 & 1 & 7 & 9 & 41 & 17 & 6 & 14 & 5 \\
\hline 28.5 & 4 & 4 & 9 & 50 & 8 & 6 & 13 & 6 \\
\hline 29 & 4 & 5 & 8 & 53 & 0 & 5 & 17 & 8 \\
\hline 29.5 & 3 & 3 & 7 & 49 & 6 & 5 & 18 & 8 \\
\hline 30 & 5 & 6 & 6 & 61 & 0 & 4 & 12 & 5 \\
\hline 30.5 & 3 & 6 & 5 & 51 & 6 & 5 & 19 & 5 \\
\hline 31.5 & 4 & 5 & 6 & 54 & 5 & 5 & 13 & 7 \\
\hline 32 & 4 & 5 & 8 & 52 & 0 & 4 & 18 & 9 \\
\hline 32.5 & 4 & 5 & 8 & 46 & 4 & 6 & 20 & 7 \\
\hline 33.5 & 4 & 7 & 4 & 54 & 7 & 6 & 16 & 2 \\
\hline 35 & 3 & 8 & 9 & 44 & 5 & 4 & 17 & 9 \\
\hline 37 & 5 & 10 & 8 & 50 & 4 & 3 & 14 & 5 \\
\hline 41.5 & 5 & 8 & 6 & 60 & 0 & 4 & 13 & 4 \\
\hline 46.5 & 4 & 6 & 6 & 55 & 5 & 4 & 14 & 6 \\
\hline 50 & 7 & 9 & 6 & 51 & 5 & 5 & 12 & 4 \\
\hline 55.5 & 5 & 7 & 6 & 53 & 6 & 4 & 13 & 6 \\
\hline 59.5 & 4 & 6 & 8 & 50 & 0 & 4 & 20 & 8 \\
\hline 60.5 & 5 & 7 & 9 & 50 & 0 & 6 & 15 & 8 \\
\hline 62.5 & 4 & 6 & 9 & 42 & 4 & 8 & 16 & 10 \\
\hline 63.5 & 3 & 3 & 9 & 41 & 5 & 8 & 18 & 13 \\
\hline 64.5 & 2 & 6 & 8 & 51 & 5 & 4 & 15 & 9 \\
\hline 67 & 3 & 5 & 8 & 49 & 0 & 6 & 17 & 11 \\
\hline 67.5 & 2 & 4 & 5 & 59 & 5 & 4 & 14 & 8 \\
\hline 68.5 & 4 & 5 & 8 & 46 & 6 & 6 & 15 & 10 \\
\hline 69.5 & 3 & 5 & 6 & 52 & 5 & 6 & 16 & 7 \\
\hline 74.5 & 4 & 6 & 7 & 48 & 5 & 6 & 17 & 7 \\
\hline 79.5 & 6 & 5 & 6 & 47 & 5 & 6 & 18 & 6 \\
\hline
\end{tabular}




\begin{tabular}{|c|c|c|c|c|c|c|c|c|}
\hline $\begin{array}{l}\text { Depth } \\
(\mathrm{cm})\end{array}$ & $\begin{array}{l}\text { Quartz } \\
(\%)\end{array}$ & $\begin{array}{c}\text { Calcite } \\
(\%)\end{array}$ & $\begin{array}{l}\text { Dolomite } \\
\quad(\%)\end{array}$ & $\begin{array}{l}\text { Clay } \\
(\%)\end{array}$ & $\begin{array}{l}\text { Plagioclase } \\
\qquad(\%)\end{array}$ & $\begin{array}{l}\text { Hematite } \\
(\%)\end{array}$ & $\begin{array}{c}\text { Goethite } \\
(\%)\end{array}$ & $\begin{array}{c}\text { Hydro-magnesite } \\
(\%)\end{array}$ \\
\hline 81.5 & 8 & 5 & 6 & 53 & 6 & 5 & 14 & 4 \\
\hline 86 & 5 & 7 & 9 & 43 & 4 & 9 & 16 & 7 \\
\hline 88 & 4 & 6 & 8 & 47 & 6 & 4 & 17 & 7 \\
\hline 95.5 & 5 & 7 & 7 & 53 & 6 & 5 & 12 & 5 \\
\hline 99.5 & 5 & 6 & 8 & 56 & 5 & 5 & 14 & 2 \\
\hline 100.5 & 2 & 2 & 6 & 52 & 5 & 4 & 21 & 7 \\
\hline 101.5 & 3 & 6 & 5 & 53 & 3 & 0 & 22 & 7 \\
\hline 104.5 & 4 & 8 & 9 & 47 & 6 & 8 & 18 & 0 \\
\hline 107.5 & 4 & 6 & 9 & 51 & 5 & 3 & 17 & 5 \\
\hline 109.5 & 5 & 6 & 8 & 52 & 6 & 5 & 17 & 0 \\
\hline 112.5 & 3 & 7 & 6 & 49 & 3 & 4 & 19 & 9 \\
\hline 114.5 & 5 & 7 & 10 & 46 & 5 & 4 & 16 & 6 \\
\hline 115.5 & 2 & 6 & 9 & 52 & 5 & 4 & 11 & 10 \\
\hline 117.5 & 3 & 5 & 9 & 56 & 5 & 6 & 10 & 9 \\
\hline 120.5 & 2 & 8 & 8 & 45 & 6 & 8 & 18 & 6 \\
\hline 123.5 & 6 & 7 & & 54 & 5 & 4 & 14 & 5 \\
\hline 126.5 & 4 & 6 & 7 & 51 & 4 & 7 & 14 & 7 \\
\hline 129.5 & 4 & $5 \%$ & 7 & 46 & 5 & 4 & 22 & 8 \\
\hline 132.5 & 5 & 6 & 7 & 47 & 6 & 5 & 17 & 7 \\
\hline 139.5 & 5 & 7 & 6 & 52 & 5 & 5 & 15 & 6 \\
\hline 144.5 & 5 & 7 & 7 & 54 & 4 & 5 & 13 & 5 \\
\hline 149.5 & 5 & 5 & 7 & 57 & 0 & 4 & 16 & 5 \\
\hline 154.5 & 6 & 8 & 6 & 54 & 6 & 5 & 12 & 5 \\
\hline 159.5 & 6 & 7 & 6 & 58 & 6 & 4 & 10 & 3 \\
\hline 162.5 & 7 & 8 & 6 & 55 & 6 & 4 & 11 & 3 \\
\hline 170.5 & 6 & 7 & 5 & 59 & 6 & 3 & 11 & 2 \\
\hline 174.5 & 6 & 7 & 5 & 61 & 6 & 4 & 9 & 2 \\
\hline 179.5 & 8 & 9 & 7 & 53 & 6 & 3 & 12 & 3 \\
\hline 189.5 & 6 & 10 & 7 & 55 & 7 & 4 & 10 & 3 \\
\hline 194.5 & 9 & 7 & 6 & 52 & 10 & 4 & 11 & 0 \\
\hline 199.5 & 6 & 6 & 7 & 57 & 7 & 3 & 12 & 2 \\
\hline 204.5 & 8 & 7 & 6 & 6 & 7 & 2 & 0 & 2 \\
\hline 206.5 & 7 & 10 & 6 & 68 & 6 & 3 & 0 & 0 \\
\hline 208.5 & 5 & 5 & 8 & 55 & 5 & 4 & 14 & 5 \\
\hline 212.5 & 4 & 5 & 9 & 49 & 5 & 5 & 17 & 8 \\
\hline 214.5 & 5 & 7 & 9 & 50 & 5 & 4 & 15 & 6 \\
\hline 216.5 & 5 & 8 & 8 & 55 & 6 & 3 & 10 & 5 \\
\hline 227.5 & 6 & 8 & 8 & 61 & 6 & 3 & 9 & 0 \\
\hline 230.5 & 1 & 9 & 6 & 51 & 12 & 6 & 15 & 0 \\
\hline 234.5 & 7 & 11 & 6 & 58 & 7 & 2 & 10 & 0 \\
\hline 239.5 & 7 & 11 & 5 & 70 & 8 & 0 & 0 & 0 \\
\hline
\end{tabular}

